\title{
Spiff, Polish, and Consumer Demand Quality: Vertical Price Restraints Revisited
}

\author{
Warren S. Grimes
}

TABLE OF CONTENTS

Introduction $\ldots \ldots \ldots \ldots \ldots \ldots \ldots \ldots \ldots \ldots \ldots \ldots \ldots, 817$

I. The Sylvania View of Vertical Restraints ............. 820

II. The Competitive Effects of Dealer Brand Promotion Activity ................................. 822

A. Brand Promotion as a Procompetitive Force ........ 822

B. The Varying Impact of Non-Informational Promotion . 825

C. Vertical Restraints and Consumer Demand Quality .... 828

D. The Classic Car Wax Story ................... 832

E. Selling with Spiff: Consumer Electromic Products ..... 834

F. Spiff and Polish: The Big Picture............... 837

III. Reassessimg the Economic Debate on Retail Price-Fixing ... 840

A. The Procompetitive Side of Vertical Price-Fixing ...... 840

1. The Expanded Free Rider Rationale............ 841

2. Avoidimg Loss Leaders........................ 843

3. Image Certification ...................... 844

B. Welfare Losses from Vertical Price-Fixing .......... 846

1. Momitoring and Enforcement Costs............ 846

2. Loss of Retail Intrabrand Competition.......... 848

C. Dynainic Efficiency in Distribution............... 848

D. The Welfare Balance Sheet for Vertical Price-Fixing ... 850

Conclusions ......................................... 853 



\title{
Spiff, Polish, and Consumer Demand Quality: Vertical Price Restraints Revisited
}

\author{
Warren S. Grimes†
}

The United States Supreme Court has been increasingly tolerant of vertical price restraints. Commonly, such restraints require retailers to sell a brand name product at or above a minimum price set by the producer. The Court has concluded that vertical price restraints may benefit consumers by encouraging the entry of new producers into a market, increasing the level of interbrand competition. In this Article, Professor Grimes offers a critical analysis of the advantages offered by vertical price restraints and describes a variety of the restraints' welfare costs. In particular, Professor Grimes explores the possibility that vertical price restraints encourage misleading brand promotion by dealers. Using as examples restraints in the consumer electronics and car wax markets, Professor Grimes demonstrates the potential for consumers to make less informed, less competitive purchasing decisions. The Article concludes that a careful weighing of the actual benefits and costs of vertical price restraints suggests very few cases in which vertical price restraints will have a net procompetitive effect, and even fewer in which that benefit could not be attained by less anticompetitive means.

\section{INTRODUCTION}

In March 1975, a witness told a congressional subcommittee a stirring tale of a David who had stood up to not one, but a whole series of Gohaths. Starting as an unknown and coinpeting against inuch larger established companies, the witness told how his firm had profitably estabhished the "Classic" line of car waxes as a national competitor. ${ }^{1}$ As he saw it, the ingredients of his success were a high quality product and the

$\dagger$ Professor, Southwestern University School of Law. B.A. 1965, Stanford University; J.D. 1968, University of Michigan. The author was Chief Counsel of the Monopolies and Coniniercial Law Subcommittee of the House Judiciary Comnittee from 1980 to 1988.

Peter C. Carstensen, George E. Garvey, F.M. Sclierer, Robert L. Steiner, and Lawrence A. Sullivan provided insightful comnents on earlier drafts. Terri M. Hinsley and Stephen Mattern provided valuable research and editorial assistance. The materials presented renuain the responsibility of the author. The research and writing of this paper were supported by a grant from Southwestern University School of Law.

1. See Fair Trade: Hearings on H.R. 2384 Before the Subcomm. on Monopolies and Commercial Law of the House Comm. on the Judiciary, 94th Cong., 1st Sess. 50, 51-52 (1975) 
use of a vertical price-fixing scheme that allowed retailers to "make money."2

In most cases, a vertical price-fixing scheme requires each retailer to sell a branded product at or above a minimum price set by the producer. ${ }^{3}$ The car wax story focuses on a key point in the debate over antitrust pohicy governing such fixed retail prices: whether they enhance or hinder competition beneficial to consumers. This Article addresses that debate. The car wax marketing success, offered to Congress to demonstrate the procompetitive value of fixed retail prices, does not support that conclusion. Instead, it raises troublesoine questions about the anticompetitive potential of retailer brand promotion linked to vertical price-fixing.

Part I of this Article describes Supreme Court interpretations of antitrust law that are sympathetic to vertical restraints, including vertical price-fixing. These interpretations rest upon the premise that vertical restraints benefit consumers by increasmg competition among brands (interbrand competition). Under this view, restraining competition among dealers of the same brand (intrabrand competition) is a necessary cost of obtaining the greater benefits of enhanced interbrand competition. For a number of reasons developed in Parts II and III, these conclusions are misleading and an unsatisfactory basis for formulating antitrust policy toward vertical price-fixing.

Part II addresses a problein so far ignored by the Court and undeveloped by the relevant literature: the hink between vertical restraints and dealer incentives for brand promotion likely to decrease the quality of consumer demand. ${ }^{4}$ Overall, brand promotion may have a procompetitive effect upon our economy: when such promotion increases consumer information about alternatives, it benefits competition. But brand proinotion can be anticompetitive if it leads a consumer to make less competitive choices than the purchaser would otherwise make. As Part II explaims, the hikelihood and extent of consumer injury from inisleading brand proinotion will vary depending on the type of product being sold.

Part II also examines differences between retailer and producer brand promotion. Consuiners can grasp the self-interest that motivates producer brand proinotion. In dealer brand promotion, self-interest can be hidden-consumers may be unaware that a dealer benefits by selling one brand over another. Moreover, although both producers and dealers may occasionally dispense inaccurate information, dealer promotion abuses are often inore difficult to inonitor and control. Part II examines

[hereinafter House Fair Trade Hearings] (statement of Curtis L. Bruner, President, Classic Chemicals, Ltd.).

2. See id. at 51,6465 .

3. The fixing of maximum resale prices raises somewhat different issues not addressed here.

4. The idea has been touched upon, however, in at least one recent Article. See Barbara A. White, Black and White Thinking in the Gray Areas of Antitrust: The Dismantling of Vertical Restraints Regulation, 60 GEO. WASH. L. REV. 1, 58 (1991). 
the welfare effects of retailer brand promotion fostered by vertical pricefixing in the sale of two contrasting types of consumer products: car wax and consumer electronic products. Although welfare effects will vary with the type of product, it is likely that negative effects will occur whenever a branded product is marketed through on-site dealer promotion. These conclusions are consistent with the pattern of litigated cases imvolving vertical price restraints.

Part III attempts to integrate this largely unexplored anticompetitive potential of vertical price-fixing witl current economic learning. Three potential competitive benefits of the use of vertical price restraints are explored: enhancing dealer services under the expanded free rider rationale offered by some theorists, ${ }^{5}$ preventing loss leader selling, and obtaining dealer certification services. For the most part, these tlieories fail to demonstrate wly producers could not use less competitively mjurious methods to obtain the saine benefits. Whatever welfare-enhancing effects arise from vertical price-fixing must be of sufficient magnitude to overcome three welfare costs of such scliemes: (1) any reduction in the quality of consumer demand arising from the use of vertical price-fiximg at the retail level; (2) the cost of implementing and enforcing the pricefixing scheme; and (3) tlie loss of intrabrand competition at the retailer level. Part III also examines the prominent role of retailers and distributors im the overall distribution system and the possibility that vertical price restraints inhibit innovation in that system. Finally, it exammes recent studies that suggest strong welfare-reducing effects from vertical restraints applied at the retailer level. Contrary to the Supreme Court's assumption, in these cases, vertical restraints either failed to increase imterbrand competition or failed to increase it sufficiently to offset the loss in intrabrand competition.

I conclude that after a century of debate, one can say that vertical price-fixing, when it works well, can increase dealer promotion and service activity by transferring the cost of that activity to the consumer. Unquestionably, it can raise profits for retailers. Under relatively narrow circumstances, it may benefit consumers by attracting inore buyers to a desired product. But the welfare costs of vertical price-fixing reviewed here are substantial and in most cases will outweiglı any gains. These conclusions have implications for antitrust policy toward vertical pricefixing and otler vertical restraints with smilar restraining effects on retail competition.

5. See Benjamin Klein \& Kevin M. Murphy, Vertical Restraints as Contract Enforcement Mechanisms, 31 J.L. \& ECON. 265 (1988). 
I

\section{The SYLVANIA VIEW OF Vertical RESTRAINTS}

In the landmark case of Dr. Miles Medical Co. v. John D. Park \& Sons $C o .{ }^{6}$ the Supreme Court declared a conspiracy to fix retail prices to be a violation of the Sherman Act. The Court cited with approval a lower court's conclusion that under such a price-fixing scheme, "competition between retailers, who supply the public, is made impossible."7 It also recognized that such a scheme was im the interest of retailers and, perhaps, initiated at their behest. ${ }^{8}$ Starting from this premise, opponents of vertical price-fixing point out that, because such schemes eliminate direct price competition on the branded item, they force consuiners to pay higher prices. The evidence that consumers pay more is largely undisputed. ${ }^{9}$

Proponents of vertical price-fixing contend, however, that higher prices bring an enhanced product or service. They further contend that society benefits from such pricing practices because producers use thein to increase sales of desired products and, accordingly, these practices result in an overall increase in desired goods and services. ${ }^{10}$ In this way, consumers actually benefit, it is argued, from vertical price-fixing. ${ }^{11}$ In its recent decisions involving vertical restraints, the Supreme Court has followed this reasoning.

In Continental T.V., Inc. v. GTE Sylvania Inc., ${ }^{12}$ the Supreme Court declared that vertical restraints can be procompetitive by facilitating dealer promotion and adopted a rule-of-reason test-a more tolerant standard than the then-existing per se rule-for all vertical restraints other than vertical price-fixing. ${ }^{13}$ In Business Electronics Corp. v. Sharp Electronics Corp. ${ }^{14}$ the Court extended this rationale to conduct that had the same economic mipact as price-fixing; it apphed the rule of reason to a producer who had terminated a discounting retailer. The Court declined to apply the stricter per se rule because the producer had made

6. 220 U.S. 373 (1911).

7. Id. at 400 .

8. See id. at 407. For a discussion of the retail druggists' involvement in the Dr. Miles case and other efforts to maintain retail prices, see Peter C. Carstensen, Vertical Restraints and the Schwinn Doctrine: Rules for the Creation and Dissipation of Economic Power, 26 CASE W. RES. L. REV. 771, 811-14 (1976).

9. See, e.g., William S. Comanor, The Two Economics of Vertical Restraints, 5 REv. INDus. ORGANIZATION 99, 100-01 (1990) (discussing evidence that vertical price restraints lead to higher prices).

10. Consumers may prefer fewer but more desirable goods and services, so the "maximum" allocation is not necessarily that in which the largest amount of goods and services are distributed.

11. See Robert H. Bork, The ANTITRUST Paradox 290 (1978) ("Since vertical restraints are not means of creating restriction of output, we must assume that they are means of creating efficiencies, and it is perfectly clear that they are.").

12. 433 U.S. 36 (1977).

13. See id. at $54-55$.

14. 485 U.S. 717 (1988). 
no agreement with retailers on a specific retail price. ${ }^{15}$

In both of these cases, the Court's reasoning rests on the asserted benefits to interbrand competition resulting from intrabrand restraints. The Court argued in Sylvania that vertical restraints promote imterbrand competition by allowing the manufacturer to achieve efficiencies in distribution:

For example, new manufacturers and manufacturers entering new markets can use the restrictions im order to induce competent and aggressive retailers to make the kind of investınent of capital and labor that is often required in the distribution of products unknown to the consumer. Established manufacturers can use them to induce retailers to engage in promotional activities or to provide service and repair facilities necessary to the efficient marketing of their products. ... . The availability and quality of such services affect a inanufacturer's goodwill and the competitiveness of his product. Because of market imperfections such as the socalled "free rider" effeet, these services might not be provided by retailers in a purely competitive situation, despite the fact that each retailer's benefit would be greater if all provided the services than if none did. ${ }^{16}$

The Court reasoned that where interbrand competition exists, it "provides a significant check on the exploitation of intrabrand market power" because consumers could switch to a competing brand. ${ }^{17}$ Echoing this line, the Court in Sharp added that prohibiting vertical restraints "would create a perverse imcentive for inanufacturers to integrate vertically into distribution, an outcome hardly conducive to fostering the creation and maintenance of small businesses."18

In Sylvania, the Court took a producer-centered view of vertical restraints. The Court was careful, however, to distinguish price restraints from other vertical restraints, noting that price-fixing could be a vehicle for retailer-instigated cartel activity. ${ }^{19}$ Although it paid homage to this language, the Court in Sharp essentially ignored it, and focused instead on the Sylvania presumption that vertical restraints enhance interbrand competition, which is "the primary concern of antitrust law."20 The Court's assumption that competition among producers (interbrand competition) is the primary engine which drives coinpetition is, for reasons discussed in Part III, misleading and an inadequate basis for formulatimg policy toward vertical restraints. It is now recognized

15. See id. at 726-36.

16. Sylvania, 433 U.S. at 55.

17. Id. at 52 n.19.

18. Sharp, 485 U.S. at 725 (citing Sylvania, 433 U.S. at 57 n.26).

19. See Sylvania, 433 U.S. at 51 n.18.

20. Sharp, 485 U.S. at 724 (quoting with approval Sylvania, 433 U.S. at 52 n.19). In dissent, Justice Stevens appears to read Sylvania even inore broadly when he states that "a demonstrable benefit to interbrand coinpetition will outweigh the harm to intrabrand competition that is caused by the inposition of vertical nonprice restrictions on dealers." Id. at 749 (Stevens, J., dissenting). This language suggests that any benefit to interbrand competition, no unatter how small, might be enough to counter even the total elimination of intrabrand competition. 
that retailers who seek to maintain retail profit margins are most often the primary force behind retail price maintenance. ${ }^{21}$ The analysis of dealer brand marketing which follows is not, however, dependent on who initiates the vertical price-fixing scheme. This analysis suggests a concern with vertical restraints that the Court has yet to address: the potential anticompetitive effect of on-site, dealer brand promotion activity fostered by vertical restraints.

\section{II}

\section{The Competitive Effects of Dealer Brand Promotion ACTIVITY}

\section{A. Brand Promotion as a Procompetitive Force}

Informative brand promotion, whether by producers or dealers, can substantially benefit consumers. It allows a buyer to make repeat purchases of a product with desired characteristics and to avoid others with undesired characteristics; it increases the producer's incentive to produce a consistently high quality product to maintain the goodwill of his brand; it allows the producer to obtain broad distribution of the product, greatly increasing opportunities for lower cost, high voluune production and marketing; and it allows the producer to market an innovative product to an otherwise unreceptive public. ${ }^{22}$ Phillip Nelson has argued that products can be profitably advertised over a longer period only if they ineet consumer expectations; thus, widely advertised products are, in Nelson's view, usually a wise purchase decision. ${ }^{23}$ Robert Steiner

21. See Ward S. Bowman, Jr., Resale Price Maintenance-A Monopoly Problem, 25 J. Bus. U. CHI. 141, 149-51 (1952) (analyzing liquor retailer examples); Comanor, supra note 9, at 110-14 (discussing the role of retailers in maintaining vertical restraints); Robert L. Steiner, The Nature of Vertical Restraints, 30 ANTITRUST BULL. 143, 164 (1985) (discussing "bogus" vertical restraints). Retailers and distributors can also force adoption of nonprice vertical restraints. See Peter F. Carstensen \& Richard F. Dahlson, Vertical Restraints in Beer Distribution: A Study of the Business Justifications for and Legal Analysis of Restricting Competition, 1986 WIS. L. REV. 1, 41-43. For further discussion, see infra Section III.C.

22. The economic theory justifying use of trademarks is discussed in Niclolas $\mathbf{S}$. Economides, The Economics of Trademarks, 78 TRADEMARK REP. 523, 525-27 (1988). Steiner adds tliat brand promotion may enable a producer to market an innovative product. See Robert L. Steiner, Judging the Welfare Performance of Manufacturers' Advertising, 10(3) J. ADVERTISING 3, 10 (1981) [hereinafter Steiner, Manufacturers' Advertising]. Steiner has also shown that brand promotion advertising may increase the producer's profit margin by raising consumer demand, increasing production efficiencies, and forcing retailers to cut profit margins to maintain customer trade in a popular branded item. Notwithstanding a higher producer price, the consumer may pay a lower retail price as the result of intensified competition between retailers. See Robert L. Steiner, Intrabrand Competition-Stepchild of Antitrust, 36 ANTITRusT BULL. 155, 197 (1991) [hereinafter Steiner, Intrabrand Competition]; Robert L. Steiner, Sylvania Economics-A Critique, 60 ANTITRUST L.J. 41, 56 (1991) [hereinafter Steiner, Sylvania Economics].

23. See Phillip J. Nelson, The Economic Value of Advertising, in ADVERTISING \& Soc'Y 43, 50 (Yale Brozen ed., 1974) ("The consumer is riglit in his belief that advertised brands are better. The better brands liave more incentive to advertise than the poorer brands."). An exainple of a widely advertised product that was not the best purchase is offered by Willard F. Mueller, The Sealy 
describes the role producer brand promotion may have played in breaking down "the Keystone" (one hundred percent) retail markup, paving the way for the emergence of discounters who sell widely known brands at much lower markups. ${ }^{24}$ Such benefits have led knowledgeable critics to conclude that brand promotion is a net procompetitive benefit to our society. ${ }^{25}$ But brand marketing can also have substantial anticompetitive effects.

Under the theory of perfect competition, consumers purchase a fungible item with no brand differentiation. The consumer's task is easy. All producers offer identical products, so the buyer need only compare price in order to make the most competitive purchase. Real world markets are more complex, placing a far greater burden on the consumer to make the right choice. Even apparently identical products may differ in quality. More complex products that serve the same function vary substantially in construction, quality, features, and price. To duphicate the perfect competitive performance that is assumed in many microeconomic models, the consumer must have perfect information: complete and accurate knowledge of the product-price mix of all available products. ${ }^{26}$ But in any real market, there are a number of ways in which consumers might be attracted to a particular brand for reasons other than the superiority of its product-price mix. ${ }^{27}$ Depending on the circumstances, consumers may or may not end up with the choice that they would make under ideal competitive conditions. Economists sometimes refer to the consumer's ability to make purchases consistently with perfect competi-

Restraints: Restrictions on Free Riding or Output?, 1989 WIs. L. Rev. 1255, 1278 (describing the relatively low test rating given to Sealy Posturepedic Mattresses, a heavily advertised product selling at a higher price than more highly rated brands).

24. See Steiner, Manufacturers' Advertising, supra note 22, at 11.

25. See NeIL H. Borden, THE ECONOMIC EFFECTS OF ADVERTISING $881-82$ (1942); Steiner, Manufacturers' Advertising, supra note 22, at 12-13. For a summary of the possible benefits and detriments of advertising, see F. M. SCHerer \& David Ross, INDUSTRIAL MARKET STRUCtURE AND ECONOMic Performance 572-92 (3d ed. 1990).

26. For economists, a competitive price would be the marginal cost of producing and distributing a product, a condition that would likely be approached only if there were a large number of producers of an undiferentiated product. See SCHERER \& Ross, supra note 25, at 15-18 (defiring competition). When products are differentiated by brands, perfect competition assumes a consumer's complete knowledge of the price and characteristics of all competing products. See Lawrence A. Sullivan, Warenzeichen und Behinderungspraktiken in den USA: Eine vorläufige Analyse, 1983 GEWERBLICHER RECHTSSCHUTZ UND URHEBERRECT, INTERNATIONALER TEIL $714,716$.

27. The unajority opinion in Sylvania rejects Professor Comanor's argument that vertical restraints decrease interbrand competition by promotiug product differentiation. With no accompanying analysis and no theoretical or empirical support, the Court simiply observed: "This argument is fiawed by its necessary assumption that a large part of the promotional efforts resulting from vertical restrictions will not convey socially desirable information about product availability, price, quality, and services." Continental T.V., Inc. v. GTE Sylvania Inc., 433 U.S. 36, 56 n.25 (1977) (addressing the comments directly to Professor Comanor's argument). Section II.C of this Article explains why point-of-sale dealer promotion fostered by vertical restraints is more likely to be anticompetitive than promotion activity at the producer level. 
tion as the quality of consumer demand. ${ }^{28}$

Circumstances that could lead a consumer to a skewed buying choice might be a lack of information or the presence of misleading or irrelevant information. The fault may he with consumers, who may misidentify brands. But skewed buying choices are often the result of noninformational promotion activity-promotion that is either misleading or conveys no relevant information to the consumer. A producer or retailer can skew consumer choices through deceptive advertising or through less overt strategies, such as miage advertising or prominent shelf display. Although the quality of consumer demand will never achieve the ideal, public pohicy should be formulated with recognition that demand quality will vary with changes in mcentives that affect promotion. Rules of law that encourage or tolerate practices likely to lower rather than raise the quality of consumer demand are suspect. Vertical price restraints are likely to lower the quality of consumer demand by encouraging noninformational brand promotion by retail dealers, the self-interested nature of which is hidden from consumers.

There is an incentive for a seller to rely on non-informational brand promotion whenever its use produces higher returns. ${ }^{29}$ But higher producer or dealer returns do not determine the pro- or anticompetitive status of the promotion. Even if a promotion persuades the consumer to buy an objectively superior product, the consumer may have paid too much. A cheaper product, though objectively inferior, might serve the consumer's needs at lower cost. Promotion is anticompetitive if it leads a consumer to purchase a product less desirable in its product-price mix than a product that the consumer would choose in the absence of the promotion.

In sum, brand promotion can be profitable for a seller regardless of the product's comparative worth. Although brand promotion may well be procompetitive when the product-price mix of a promoted brand is superior in the eyes of some consumers, producers will employ non-informational brand promotion whenever it is profitable, regardless of the comparative worth of the brand. ${ }^{30}$ Even if brand promotion skews con-

28. See, e.g., Steiner, Manufacturers' Advertising, supra note 22, at 3, 13.

29. If two identical items are sold with different brand names (as apparently was the case with Chlorox and Purex bleaches, see FTC v Procter \& Gamble Co., 386 U.S. 568, 572 (1967)), brand promotion going beyond price or packaging will likely be non-informational. Such noninformational promotion could be a way of incrcasing sales to a level of more effieient production and distribution. On the other hand, as Sullivan points out, advertising under such circumstances can become an entry barrier because the per unit cost of brand promotion can be much higher for a new entrant who has fewer sales. See Sullivan, supra note 26, at 719-20; see also ScHERER \& Ross, supra note 25 , at 598-600. The same could be said for brand promotion associated with products objectively inferior to the competition. No information about the product's superior characteristics can be conveyed. Still, advertising may usefully convey information about the lower price or superior servicing of such products.

30. These conclusions would appear to follow regardless of whether one views the overall impact of advertising as anticompetitive or procompetitive. Compare Yale Brozen, Entry Barriers: 
sumer buying choices away from those that would be made by wellinformed consumers, some theorists will argue that such advertising can be procompetitive because of the longer-term dynamic efficiencies that advertising can produce. ${ }^{31}$ But the likelihood of a net welfare-enhancing result is reduced as consumers are led away from the choices wellinformed buyers would make.

\section{B. The Varying Impact of Non-Informational Promotion}

The impact of non-informational promotion is likely to differ depending upon the type of good being sold. Economic writers have distinguished three categories of goods: (1) search goods-those with external attributes that the consumer can evaluate at the time of purchase; (2) experience goods-those that the consumer can adequately evaluate only after purchase and use; and (3) credence goods-those that the consumer carmot meaningfully evaluate even after using them. ${ }^{32}$ The impact of imperfect information is likely to be lowest for search goods with easily identifiable attributes: greetmg cards, for example. Consumers usually will have all the information they need to determine the desirability of buying a particular card when they see it. In contrast, the impact of noninformational promotion will be greatest when the consumer lacks the ability to assess meaningfully the quality of goods. ${ }^{33}$ An example of such a credence good imight be a prescription drug or an automobile replacement part. Even a diligent consumer may be unable to determine whether the product is needed at all, is performing as expected, or is superior in quality or price to other available products.

In the middle category (experience goods), the consumer is unable to determine a product's quality at the point of purchase and may, therefore, make a purchasing mistake. But theorists argue that the experience of owning the product will teach the consumer whether or not to purchase it agam. ${ }^{34}$ Therefore, any loss in consumer welfare is limited to the imitial buying mistake. In addition, one could argue that welfare

Advertising and Product Differentiation, in Industrial Concentration: The New Learning 115, 120 (Harvey J. Goldschmid et al. eds., 1974) with H. Michael Mann, Advertising, Concentration, and Profitability: The State of Knowledge and Directions for Public Policy, in INDUSTRIAL CONCENTRATION: THE New LeARNING, supra, at 137, 139-40 (taking opposite positions on the competitive effects of advertising but reaching similar conclusions). For a more recent discussion of advertising as a pro- or anticompetitive force, see Elizabeth Mensch \& Alan Freeman, Efficiency and Image: Advertising as an Antitrust Issue, 1990 DUKE L.J. 321.

31. See supra notes $22-25$ and accompanying text.

32. The first two categories of goods are described in Nelson, supra note 23, at 47 . The characteristics of credence goods are described in Michael R. Darby \& Edi Karni, Free Competition and the Optimal Amount of Fraud, 16 J.L. \& EcoN. 67, 68-70 (1973).

33. See Darby \& Karni, supra note 32, at 68-69.

34. See, e.g., Phillip Nelson, The Economic Consequences of Advertising, 48 J. Bus. 213, 215 (1975) ("[C]onsumers are able to determine the utility of a brand after enough purchases of that brand."); George J. Stigler, The Economics of Information, 69 J. PoL. EcoN. 213 (1961) (analyzing the cconomic effects of ignorance). 
losses due to mistakes made in purchasing some products will be offset by welfare gains when a new entrant with a superior product uses non-informational promotion to gain a market hold.

The above view of experience goods probably understates potential harm from non-informational promotion. First, it assumes that consuiners will learn from mitial purchasing decisions. This assumption seems reasonable when a product is an obvious leınon. But, for reasons explored below, inany consumers will fail to benefit from the initial buying experience. Moreover, when the product is expensive and infrequently purchased, the consumer injury from an imitial purchase inistake can be substantial. Finally, the need for non-informational proinotion for the new entrant is less compelling if less anticompetitive but still productive alternative marketing strategies exist. Price coinpetition, informative advertising (including brand promotion), and other methods of purchasing dealer proinotion services are alternative competitive tactics for a new entrant.

The harm from non-informational proinotion of experience goods will vary with frequency of purchase, cost, and coinplexity of the item. Consuiner search costs will also affect injury. ${ }^{35}$ To account for these variables, experience goods inay usefully be subdivided into high volume consumables, low volume consuinables, and durable (and often coinplex and high cost) products. ${ }^{36}$ A cola-fiavored soft drink, for example, is a high volume consumable. Although a consumer cannot experience this product without trying it, the cost of a mistaken purchase is low. Through relatively inexpensive trial and error, the consumer can easily identify a preferred brand.

Low voluine consumables are used less frequently. The opportunity to assess the performance of alternative brands is reduced. Examples might be furniture pohish or car waxes. If the product's unsatisfactory characteristics are clear, the consumer will not repurchase the item. On the other hand, if the product performs adequately, the consumer may repurchase it, not wishing to take the risk of experimentation with other brands. ${ }^{37}$ This consumer brand loyalty could lead to repeated purchases inconsistent with a high quality of consuiner deinand.

The opportunity to correct a purchasing mistake is lowest when dealing with purchases of durable goods. Although an unsatisfactory

35. See Richard Schmalensee, On the Use of Economic Models in Antitrust: The ReaLemon Case, 127 U. PA. L. REv. 994, 1036-43 (1979) (analyzing consumer behavior and search costs).

36. In his economic analysis of trademarks, Economides divides consumer goods into two categories: experience goods (those frequently purchased by the same person) and goods infrequently purchased by the same consumer (including durable goods). See Economides, supra note 22 , at $527-31$.

37. Sullivan discusses consumer risks and costs in obtaining reliable information as reasons why consumers will stick to a known brand despite the availability of superior products at lower prices. See Sullivan, supra note 26 , at 718 . 
experience with a product may cause the consumer to avoid that brand in the future, the economic loss has already been substantial-a consumer has invested a substantial sum and may be unable or unwilling to purchase another such item for many years. By the time the consumer is prepared to purchase again, the information learned from the past purchase may be dated-old deficiencies may have been corrected and new ones may have emerged. And if the purchaser's experience with the product was satisfactory, the imcentive to learn whether other more competitive choices are available is dainpened, particularly where search costs are high.

\section{RISK OF CONSUMER INJURY FROM NON-INFORMATIONAL BRAND PROMOTION}

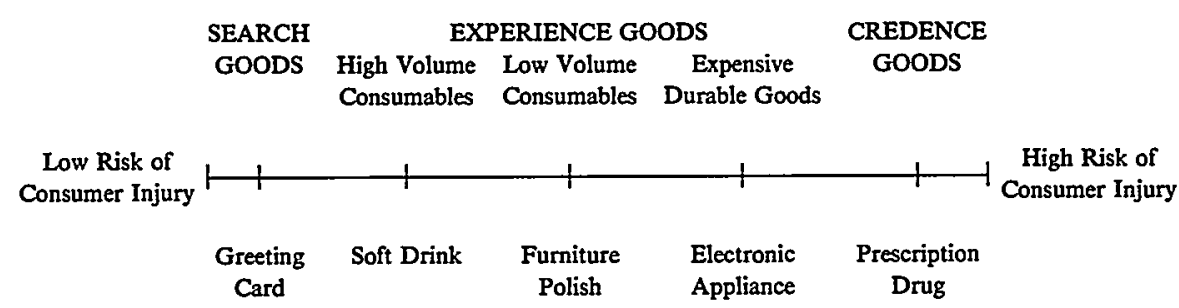

This analysis of the impact of non-informational promotion is summarized in the above chart. The lines of defimition between the various categories of goods are not always clear. Many products that fall in the first two categories (search goods or experience goods) have a credence element to them. For example, most complex durable items will be difficult for consumers to evaluate meaningfully. A purchaser of a computer or electronic stereo system will have great difficulty in obtaining complete information about the full range of market alternatives. A consumable such as a soft drink or furniture polish may also have credence features. At the time of use, the consumer may form an impression about the product's performance but may be ill-equipped to assess some attributes, such as its long-term environmental or health risks.

In all categories of goods, non-informational promotion may lead consumers to anticompetitive purchase decisions by obscuring the relative merits of competing goods. A manufacturer of greeting cards (a search good) might deceptively claim that its cards are printed on recycled paper. This assertion, difficult for the consumer to verify, might infiuence some buyers. Moreover, search costs may allow a retailer to charge higher, less competitive prices on many low cost items. A retailer's decision to stock a particular hine of greeting cards (perhaps because it offers retailers a higher return) can lead consumers to pay more to avoid the cost of searching at another store. Search costs may also explain why some supermarkets will price food items competitively but stock their shelves with non-food items at higher, less competitive 
prices. Purchasers who come to the store primarily to buy food may purchase the other goods for convenience (and with less attention to price).

Thus, although the likelihood of distorted buying choices will vary with the characteristics of the product being sold, even for search goods, there is a possibility that brand promotion will lead consumers to less competitive buymg choices. For some purchases, such as expensive durable goods, the consumer injury can be substantial. On the other hand, the hikelihood that brand promotion will skew some consumer buynig choices niay not be a sufficient reason for restricting such activity. As discussed in Section II.A above, brand proniotion can generate brand loyalty that fosters higher consumer deinand for desired products and produces a number of welfare-enhancing efficiencies.

Society's tolerance of most forms of brand promotion nuay be explained not only by its potential benefits but also because the potential for injury is limited. Many overt forms of fraud or deceptive advertising can be prosecuted. Moreover, the consumer is able to discount a great deal of the huff and puff associated with advertising. For exaniple, the self-interested notivation behind a national advertising campaign for a corporation is difficult to disguise. If consumers understand that proinotion steins from the producer, they can discount its value accordingly. The picture is more troubling when brand promotion is carried out at the dealer level.

\section{Vertical Restraints and Consumer Demand Quality}

The Court in Sylvania ignored a fundamental prenise for any vertical restraint: it has econonic value only when brand distinctions are translated into brand loyalty that undercuts competition between brands. ${ }^{38}$ For example, in the absence of a market-wide cartel, it is a precondition of any successful mininuun vertical price restraint that the producer's product have a brand name that distinguishes it from the conipetition. ${ }^{39}$ Moreover, the distinction must be one that can attract the consumer. Unless consuniers want, or can quickly be induced to want, the price-fixed product more than alternative brands, they will not pay

38. As Bowman puts it, "[p]rice maintenance appears to be incompatible with an assumption of pure competition amoug both sellers and resellers. In economic terms it is the 'monopoly' aspect of markets rather than the 'competitive' aspect which is most relevant to an understanding of the motivations for resale price maintenance." Ward S. Bowman, Jr., The Prerequisites and Effects of Resale Price Maintenance, 22 U. CHI. L. Rev. 825, 849 (1955). A similar point is made in Peter C. Carstensen, Legal and Economic Analysis of Distribution Restraints: A Search for Reality or MythMaking?, in Issues AfTER A CENTURY OF FEDERAL COMPETITION POLICY 79, 82 (Robert L. Wills et al. eds., 1987).

39. Among the major justifications offered for vertical price-fixing are that it allows producers to build and maintain the goodwill affiliated with their names or the marketing images of their products. See Bowman, supra note 38 , at 833-34. 
the higher price to purchase it. ${ }^{40}$

On its face, this reasoning suggests that vertical restraints will be associated with less, not more, competition between brands, undermining the Court's premise that such restraints foster interbrand competition. Yet the Court's premise might be correct if a consumer were, as a result of vertical restraints, more likely to choose a competitively superior brand. Alas, for reasons developed in this Section, vertical price restramts, by shifting incentives for brand promotion from the producer to the retailer, enhance the risk of non-informational promotion, the selfinterested motivation for which may be hidden from the consumer.

The Sylvania Court was correct in recognizing that vertical restraints allow the producer to shift the burden and risk of promotion to the retailer. Like strong distributional restrictions that limit dcaler competition, vertical price-fixing can transfer virtually the entire cost of brand proinotion to the dealer (subject to the producer's enforcement costs)..$^{41}$ The dealer is paid for its promotion through the increased return from the fixed resale price. There are, of course, other ways that a producer can buy loyalty and promotional activity froin dealers. ${ }^{42}$ Most prominently, a producer can purchase proinotional activity through direct payments to the retailer, known as promotional or display allowances. For example, a producer can pay a retailer to carry a product or to shelve it prominently. Dealer promotion can have the same effects on a consumer whether it is paid for by direct payments or indirectly through vertical restramts. ${ }^{43}$ But direct payments differ from vertical restraints in that they do not shift the cost of performance directly to the consumer. The producer's higher costs in paying for promotion may be passed on to the retailer in higher producer sales prices, but

40. The interrelationship between brand marketing and vertical restraints is explored in William S. Comanor, Vertical Territorial and Customer Restrictions: White Motor and Its Aftermath, 81 HARV. L. REV. 1419, 1422-26 (1968). As Coinanor explains, both the producer and the retailer can benefit from the retailer's higher fixed resale price when the extra margin is used to promote a higher volume of sales to the consuiner at the expense of a coinpetitor's brand. See id.

41. As discussed infra Seetion III.B, vertical restraints do not guarantee that the dealer will actually perform the promotional activity desired by the manufacturer. The dealer may pocket the additioual inargin in exactly the manner of a dealer-organized cartel.

A distribution system in which a consumer has only a single retail source of a manufacturer's product (an "airtight" exclusive territory for a retailer) will have the same potential for transferring costs as vertical price-fixing and may lessen incentives for dealers to cheat. But it achieves this success through enhancing the cartel effects of vertical restraints. In practice, such distribution systeins inay be less of a problem than it might appear because they are unattractive to any producer looking for the broadest possible retail distribution of its product.

42. The welfare implications of one of these alternatives to vertical restraints are reviewed in Robert L. Steiner, Manufacturers' Promotional Allowances, Free Riders and Vertical Restraints, 36 ANTTrRUST BULL. 383 (1991) (analyzing promotional allowances).

43. Absent contractual enforcennent of the promotional allowance (or vertical restraints), direct payments to dealers can be passed on to the consuiner as lower prices. Even if the producer enforces performance of the promotional activity, if some retailers are able to perform that promotion more efficieutly, they can pass on the savings to the consumer. 
intrabrand retail competition can force dealers to absorb some of this promotion cost. ${ }^{44}$ With vertical price-fixing, these consumer benefits of intrabrand competition are lost.

Even if retailer promotion paid for by vertical price-fixing had no greater probability of being anticompetitive than a producer's own promotion campaign, the additional competitive costs of vertical price-fixing (discussed in Part III below) would distinguish it from other promotion. But retailer-generated proinotion is a uniquely powerful tool for skewing consunier buying choices. As described below, inany forms of retail brand proinotion are inexpensive, very effective in altermg buyer decisions in a manner that decreases the quality of consunier demand, and difficult to momitor and control to prevent abuses.

The retailer makes decisions about which items to carry and where to shelve them. In the case of more expensive goods, sales personnel are likely to confront the consunier directly to discuss product choices. The dealer's cost in switching these promotion efforts froin one brand to another is very small. Yet that choice will substantially influence consuniers' decisions. Dealer promotion activity is effective in part because it can be efficiently targeted. Consuniers generally enter a retail store with intent to purchase. A producer engaged in media advertising, even when selecting a targeted publication (for example, a magazine for lawyers), must direct promotion at an audience, many meinbers of which have no immediate mterest in the product. In contrast, the dealer directs promotion at a person whose presence in the store indicates an interest in buymg the product. Dealer promotion can also be effective because of the person-to-person contact with the consumer, a dimension lacking in media advertising.

So far, this reasoning supports only a conclusion that both pro- and anticompetitive promotion will be more effective at the dealer level. But because consumers understand most retailers to be owned and operated independently of the producer, inost consumers enter a store unaware of the financial imcentives that cause a dealer to favor a certain brand. The consunier knows that the retailer wants to inake a sale, but has little reason to suspect that a retailer will promote a particular brand for reasons other than its merits. In short, consumers often may view retailers as neutral, advice-giving marketers, raising the risk that consumers will accept the retailer's self-interested purchase advice. ${ }^{45}$

Retailers want to maintain the goodwill of their customers and, accordingly, have a financial incentive not to sell shoddy merchandise. And most salesclerks will, if asked, try to give helpful answers to consumer questions. But if the choice comes down to two adequate brands

44. See infra Section III.C (discussing the costs of vertical price-fixing).

45. If competition among retailers keeps retailer profit margins down for all products, the retailer has less financial incentive to promote one product over another. 
(which may still have material differences), one offering the retailer a higher return, the retailer will promote the financially advantageous sale. Indeed, in many cases, a company executive who has no direct contact with the public will make the decision to push one brand over another. ${ }^{46}$ Thus, a decision to carry a more profitable line instead of an equally good, low-priced line is beyond the control of most salesclerks. The same is likely true of a decision to display prominently a particular line of merchandise. These decisions can result in skewed purchase decisions because of the retailer's unspoken acts of endorsement. Moreover, retailers may pay sales personnel commissions at higher rates on products yielding higher gross markups in order to shift sales incentives to the products on which the retailer's profit is highest. This procedure may be used, for example, by retailers of expensive consumer products. ${ }^{47}$

Not all retailer brand promotion will be equally effective in swaying consumers. Buyers entering a producer-owned outlet will generally understand the affiliation and expect heavy promotion of the producer's wares. The same will be true of a dealer who sells one producer's coinmodities exclusively (as in the case of many automobile dealers). But where the retailer appears to be independent of producers, consumers will generally be unaware of vertical rewards that heighten the outlet's incentives to promote a particular manufacturer's product. The consumer's greater receptivity to such brand promotion mcreases the dealer's incentive to engage in it and the manufacturer's incentive to encourage it. Of course, the dealer's incentive for brand promotion will vary with the size of the gross margin on that brand. Typically, however, a vertically inposed minimum resale price is set to provide the retailer a substantial incentive to sell that brand. ${ }^{48}$

A partial solution to the problem of hidden self-interest in brand promotion would be to force retailers to disclose the mcentives for brand promotion that vertical restraints provide. Retailers might not do so voluntarily. Disclosure would undercut the retailer's credibility as a neutral party among competing brands, and promotional efforts would be less

46. For instance, in returning a house brand automobile battery to a discount auto parts store, the author recently experienced the division between store employees who deal with the public and the executives who make promotion and merchandising decisions. Curious to learn why the battery had failed after only one-tenth of its rated life, the author sought out a store technician who installed the batteries. He informed the author that the house brand batteries were bad products, constantly failing after only a few months of use. Two store salesclerks subsequently offered the same information to the author. Yet the store continued to promote its house brand batteries in mass media advertising and store displays.

47. See infra Seetion II.E (illustrating the use of such "spiffs" in the area of consumer electronics).

48. A producer could offer a retailer an incentive for promotion similar to vertical price-fixing in the form of a rebate based on the unit sales of the producer's product. But a per unit rebate is more closely analogons to a lower producer selling price. The retailer cannot comfortably pocket the amount of the rebate if competing retailers use the rebate to offer consumers a reduced price that attracts the nondiscounting retailer's business. 
effective. Unfortunately, mandated disclosure would be complicated and confusing for many vertical restraints-the strength of the promotion incentive may be difficult to measure and translate for the consumer. ${ }^{49}$

Dealer brand promotion's high potential for reducing the quality of consumer demand would be of less concern if abuses were easy to monitor and control. Promotional abuses at the producer level can be monitored with relative ease. A producer's advertising campaign generally must survive the in-house scrutiny of corporate counsel as well as the standards and review procedures of the media that publish it. Thereafter, it is open to public scrutiny. Federal or state regulators as well as private plaintiffs can initiate court actions. ${ }^{50}$ In contrast, the point-ofsale conduct of individual dealers and their sales personnel is far more difficult to mointor. Individual purchasers may never realize that they have been steered to a high-profit item if the product performs within the normal range. Unless the product is a lemon, a common psychological reaction of many buyers of big ticket items is to justify their purchase regardless of its objective worth. If the consumer discovers objectionable promotional conduct, most forms of retailer brand promotion, even those hikely to skew a buyer's choices, do not violate existing legal norms. ${ }^{51}$ Even if a dealer's on-site promotion does violate the law, legal redress seems unlikely. The purchaser will rarely have sufficient financial interest to take legal action. Problems of proof may be substantial, particularly if (as is likely) the unlawful promotion was conveyed orally. The consumer can take his complaints to federal or state authorities, but agencies are unlikely to prosecute without clear evidence of repeated unlawful conduct.

\section{The Classic Car Wax Story}

The marketing of Classic Car Wax is addressed here because this story was offered to the Congress as anecdotal evidence of the procompetitive effects of vertical price-fixing. The company president told of a superior product that consumers did not buy because retailers refused to handle it. He said that his company lacked the necessary economies of scale to compete on price with large producers. According to the wit-

49. A less intrusive step would be better consumer education, alerting potential buyers to the possibility of hidden dealer incentives to promote a particular brand. Although this is a desirable step, it might unnecessarily cast doubt on legitimate dealer advice, and it seems unlikely to produce more than a inodest dip in the profitability of disguised dealer promotion.

50. For example, under federal law, the Federal Trade Commission could attack a producer's disinformational advertising campaigu as an unfair or deceptive practice in violation of section 5 of the FTC Act. See 15 U.S.C. $\$ 45$ (1988) (prohibiting unfair inethods of competition). A private plaintiff may also seek relief for deceptive advertising under section 43 of the Lanham Act. See id. $\S 1125$ (a) (providing for civil action against false descriptions and false designations of origin).

51. For a discussion of when deceptive puffing or comparative advertising may violate U.S. law, see Warren S. Grimes, Control of Advertising in the United States and Germany: Volkswagen Has a Better Idea, 84 HARv. L. REv. 1769, 1794-95 (1971). 
ness, his marketing strategy, "to sell quality at a higher price," was successful only after he promised retailers a high profit margin through a retail price-fixing scheme. ${ }^{52}$

The story fits squarely the rationale of the Supreme Court for allowing vertical restraints. A new market entrant was able to fight his way onto the playing field with giants through dealer loyalty bought with vertical price-fixing. The testimony also appears consistent with the view that vertical price-fixing "by a firm with a small market share, or when the practice is not prevalent in an industry, wonld not have anticompetitive consequences." 53 But the story deserves closer scrutimy. Consumers were paying a higher price to purchase the Classic brand. The implication of the testimony is that dealers, encouraged by retail price maintenance and higher markups, offered consumers a superior product. Was Classic Car Wax superior to the competition?

Consumer Reports magazine has on a number of occasions tested automotive polishes and related products, including several sold under the Classic name. In May 1968, the magazine rated Classic Car Wax (a paste product) in a group of twenty-five one-step cleaner-polishers. The magazine reported that Classic was not likely to be found "countrywide," but was included in the survey because of its "fancy price tag." When tested, the product had some weaknesses, including a "well below average" rating for ease of application and a less-than-top rating for durability. Its overall rating was good (sixth best product annong twentyfive). But its price was the highest of any product tested (on a per ounce basis, two and one-half times that of the top-rated paste wax). ${ }^{54}$

When Consumer Reports next rated car polishes in April 1974, Classic products had achieved a degree of national prominence. The magazine rated thirty-seven cleaner-polishers for automobiles, two of them manufactured by Classic. Classic Car Wax was the most expensive paste wax tested. Classic's hiquid product had the second highest price ainong hquid waxes. Both were rated in the second highest of four categories for durability, but again each cost substantially more than the four liquid and four paste waxes in the highest category. ${ }^{55}$ In subsequent testing, soine of Classic's car products were singled out for below average or

52. House Fair Trade Hearings, supra note 1, at 51 (statement of Curtis L. Bruner, President, Classic Chemicals, Ltd.). Mr. Bruner's contention that his marketing success was solely attributable to retail price maintenance was disputed by the Chairman of the Federal Trade Commission and by a Deputy Assistant Attoruey General, who noted that the company had also promised "to repurchase from the retailer any unsold wax, thus completely insuring the retailer against any loss." H.R. REP. No. 341, 94th Cong., 1st Sess. 5 (1975).

53. Thomas R. Overstreet Jr. \& Alan A. Fisher, Resale Price Maintenance and Distributional Efficiency: Some Lessons from the Past, 3 CoNTEMP. PoL'y Issues 43, 51 (1985). Klein and Murphy similarly argue that "vertical restraints employed by transactors with no market power cannot be anticompetitive." Klein \& Murphy, supra note 5, at 295.

54. Auto Cleaner-Polishers, 33 CONSUMER REP. 240 (1968).

55. Auto Polish: A Product Whose Time Has Passed?, 39 Consumer Rep. 350, 351-52 (1974). 
inadequate performance. ${ }^{56}$

The Classic story might illustrate the power of vertical price-fixing to increase sales. Fixed retail prices may have helped a small entrepreneur gain market share. But, assuming the performance tests were accurate, ${ }^{57}$ the story fails the competitive test. Instead, it shows that a product need not provide a superior price-quality mix in order to be successfully promoted through vertical price-fixing. Classic was selling nonsuperior (and in some cases below average) products at very high prices. The promotion that caused consumers to buy this product may have been no more than a retailer's decision to carry or prominently display Classic products, or to suggest Classic products instead of others when asked for advice. But the harm to the consumer, who pays a higher price for a nonsuperior product, is no different than if the dealer had relied on unlawful, deceptive advertismg.

\section{E. Selling with Spiff: Consumer Electronic Products}

A computer store salesman recently persuaded a colleague of the author to buy a Toshiba computer printer instead of the Epson model the colleague had intended to buy at the store. The buyer is now dissatisfied with the Toshiba printer, suspicious of the salesinan's financial incentives, and convimced that the Epson model would have been the best choice.

Suspicions of the salesman's incentives might be well-founded. The author recently interviewed a former salesman for a prominent national retailer of consumer electronic products. ${ }^{58}$ The salesman reported that, except for a salary during an initial training period, his entire income was generated by commissions tied to retail sales. Although the salesman received a one percent commission on all inerchandise sold, his inajor income came from "spiffs," or payments linked to the sale of particular brands offered by the store. The salesman reported receiving a spiff of as high as fifty dollars on the sale of a $\$ 500$ television set, dwarfing the one percent commission of five dollars. ${ }^{59}$

56. In July 1981, Consumer Reports again evaluated Classic's paste and liquid waxes, along with 35 other products. This time, Classic's paste wax received the fourth highest overall rating but was rated below average in durability. The liquid product received the second lowest evaluation (it was described as a notable "deglosser" on shiny finishes). Auto Polishes: How Much Dazzle Can You Expect?, 46 CONSUMER REP. 380, 382 (1981).

In its August 1976 issue, Consumer Reports tested a related product of this company (Classic Leatler and Vinyl Care). The product had the highest price among 20 tested products but was rated in the lowest category in performance. Auto Vinyl Cleaners, 41 ConsUMER REP. $477,478-79$ (1976).

57. Consumer Reports described its testing methodology in some detail in its May 1968 issuc. See Auto Cleaner-Polishers, supra note 54, at 240-41.

58. The interview was conducted with a former salesman of a Circuit City outlet located in Soutlern Califormia. In 1989, the interviewee worked in the video products section of the store during a three-montl period that included the year-end holiday buying surge. Notes of the interview are on file with the author.

59. Telephone Interview with John Doe, former Circuit City salesclerk (Dec. 18, 1991). In 
A higher spiff on a particular brand provides a salesclerk a substantial incentive to steer the consumer toward that brand. According to the salesinan, the product code on each floor model in the store contained a number indicating the salesman's spiff if the customer purchased that brand. If, for example, the customer were interested in purchasing a nineteen-nich color television, a salesclerk could examine the stickers on nineteen-inch models to determine the amount of spiff for each brand. The salesinan reported that during the period of his einployment, the spiff provided on Toshiba television sets was among the highest. Thus, the spiff on a nineteen-inch Toshiba model selling for $\$ 500$ might be $\$ 50$. Although Sony also might offer the salesman a $\$ 50$ spiff for its comparable inodel, Sony's retail price might be higher, inaking the set harder to sell while offering no nore compensation for the salesman's additional effort.

It is unclear whether Toshiba was employing any forn of vertical restramt in connection with the sale of its consumer electromic products during the late 1980s. By themselves, the high spiffs offered to a salesperson on Toshiba sets probably had mixed welfare consequences. Toshiba sets were relatively low priced and received adequate ratings in tests run by Consumer Reports from 1988-90, roughly corresponding to the time during which the salesınan reported the high spiffs. ${ }^{60}$ Some consumers might have benefitted front a sales pitch that switched them from a more expensive brand to a Toshiba. On the other hand, the tests showed a significant number of equal or better performing sets were available at comparable or lower prices. ${ }^{61}$ A salesperson anxious to receive a high spiff on the sale of a Toshiba is unlikely to inform a consumer about the availability of more conipetitive alternatives.

addition to any spiff payments, the salesman's compensatiou package included "cheese," a $15 \%$ commission on any service contract sold to a customer. See id. Although this commission rate suggests that sale of such service contracts is highly profitable to the retailer (and may raise separate issues of consumer protection), commissions on the sale of service contracts are not relevant to the use of vertical restraints.

60. Consumer Reports reported on color television sets on a number of occasions during 198890, roughly corresponding to the fall 1989 period during which the Circuit City salesman reported receiving high spiffs on the sale of Toshiba television sets. In May 1988, the magazine rated a Toshiba 13-inch model ninth among 24 models tested; two higher rated models (and one ranked just below it) had a lower purchase price than the Toshiba. Need a Second TV?, 53 CONSUMER REP. 326, 328-29 (1988). In February 1989, a Toshiba 27 -inch model rated thirteenth among 16 models tested; one higher rated model (and one ranked just below it) had a lower purchase price. 26-Inch and 27-Inch Television Sets, 54 CoNSUMER REP. 114, 116 (1989). In February 1990, a 19-inch Toshiba model rated twelfth among 18 models tested; threc higher ranked models (and three just below it) had lower purchase prices. Televisions: Good Choices for a First or Second Set, 55 CONSUMER REP. 76, 78-79 (1990). In the first two cases, the purchase price was that actually paid by the magazine's buyers, not the manufacturer's list price. 26-Inch and 27-Inch Television Sets, supra, at 116; Need a Second TV?, supra, at 328. In the third case, the price was the estimated average price "based on prices paid and quoted during a six-month period." Televisions: Good Choices for a First or Second Set, supra, at 78.

61. See supra note 60. 
The welfare consequences are less ambiguous when both spiffs and vertical restraints are employed in connection with the sale of a product. Based on reported litigation, the use of vertical restraints (including vertical price-fixing) in the sale of consumer electronic products appears widespread. ${ }^{62}$ When strong vertical restraints guarantee the retailer a high profit margin on a particular brand, the retailer has an incentive to encourage sales of that brand by providing sales personnel higher spiffs. Whether the manufacturer pays the spiff directly, or whether it is paid indirectly through the retailer, one can expect a convergence of incentives among the retail store's owners and sales staff to proinote a particular brand. One can understand why sellers would employ such a strategy when sales staff play a key role in influencing buyer brand selection. The manufacturer/distributor is willing to pay to ensure the retailer's loyalty. The consuiner, however, is generally unaware of these financial arrangements, increasing the likelihood that a salesperson will be perceived as a neutral adviser among brands.

Intrabrand price competition tends to limit the retailer's margin on any particular brand and, in this way, limits the incentive for biased brand proinotion by dealers. But when intrabrand competition is eliminated, proinotional payinents from the manufacturer are retained by the retailer, increasing his incentive to proinote the favored brand. This increases the risk of harm to the quality of consuiner demand. When vertical price-fixing and spiffs are used in combination, incentives for hidden brand promotion can be substantial. The consumer is vulnerable to misleading advice froin a party perceived as neutral, and the credence nature of the product makes it difficult for the consuiner to reach an informed judgment on quality eitler before or after the purchase. Monitoring and control mechanisms for point-of-sale abuses are minimal and likely to be ineffective, and consuner injury, whether or not perceived, can be substantial because of the high price of the product.

62. In the past few years, state attorneys general have brought three resale price maintenance cases against major manufacturers of consumer electronic products (Mitsubishi, Nintendo, and Panasonic) and one against a large camera manufacturer (Minolta). In addition, since 1977, counting the Sharp case, there have been at least 12 other reported federal court cases involving the use of alleged vertical restraints in the sale of consumer electronic products. See Warren S. Grimes, The Seven Myths of Vertical Price Fixing: The Politics and Economics of a Century-Long Debate, 21 Sw. U. L. REv. 1285, 1313 n.149 (1992) (detailing these cases). In addition, antitrust authorities in two other countries have recently investigated or sanctioned industry participants for vertical price restraints. Japanese Agency Is Conducting Probe of Resale Price Fixing of Consumer Goods, 62 Antitrust \& Trade Reg. Rep. (BNA) no. 1559, at 422 (Apr. 2, 1992) (describing the Japan Fair Trade Commission's investigation of Sony, Matsushita, Toshiba, and Hitachi for alleged resale price maintenance practices); Administrative Fine Is Imposed on Hitachi for Exerting Pressure on Retailers' Prices, 61 Antitrust \& Trade Reg. Rep. (BNA) no. 1532, at 324 (Sept. 12, 1991) (describing the German Cartel Office's administrative fine against Hitachi for resale price maintenance "pressures"). 


\section{F. Spiff and Polish: The Big Picture}

Vertical price-fixing encourages dealers to engage in a wide variety of highly effective promotional practices that could reduce the quality of consumer demand, ranging from unlawful (but difficult to monitor) misrepresentations to more subtle product selection and shelving decisions. If such dealer behavior is widespread, a great many consumer buying decisions will likely be altered and the net imjury to consumers will be substantial. Although the examples of dealer promotion offered here are no substitute for a broader study, there is no obvious reason why the incentives for hidden dealer brand promotion would not operate in the marketing of a wide variety of consumer goods.

Vertical restraints seem less likely to affect adversely the quality of consumer demand if the restraints operate only at the distributor level and not the retailer level, if retailers sell only a single manufacturer's line of goods, or if consumers can easily assess a product's worth before purchase or from inexpensive past purchases. Absent one or more of these conditions, there is both opportumity and incentive for increasing the sales of a branded product through vertical restraints that reduce the quality of consumer demand.

This analysis suggests that the incentive for vertical price restraints is highest when the marketing of a product benefits from active dealer promotion and the product possesses credence characteristics that make it difficult for the consumer to determine its quality.$^{63}$ Recently litigated cases have involved products that fit this description. Six of seven governmental enforcement initiatives during the past ten years involved durable goods witl credence features and a high potential for dealer promotional activity. Four of these actions involved consumer electronic products. ${ }^{64} \mathrm{~A}$ fiftl and sixth involved cameras and swimming pool cleanimg appliances. ${ }^{65}$ The seventh involved cosmetics, an experience good with credence features often sold with the aid of image advertising and dealer promotion. ${ }^{66}$

Private enforcement also fits this pattern. The Supreme Court's two landmark cases of the 1980s, Sharp (electronic calculators) ${ }^{67}$ and Monsanto (agricultural chemicals), ${ }^{68}$ involved products with credence fea-

63. See supra Section II.B.

64. Nintendo of Am., Inc., 56 Fed. Reg. 15,883 (FTC 1991) (proposed consent order) (home video game hardware); Maryland v. Mitsubishi Elecs. of Am., Inc., 60 Antitrust \& Trade Reg. Rep. (BNA) 446 (D. Md. Mar. 27, 1991) (TV sets); In re Panasonic Consumer Elec. Prod. Antitrust Litig., 1989-1 Trade Cas. (CCH) \ 68,613 (S.D.N.Y. 1989) (Panasonic and Technics electronic products); Onkyo U.S.A. Corp., 100 F.T.C. 59 (1982) (consent order) (audio components).

65. Minolta Camera Prod. Antitrust Litig., 668 F. Supp. 456 (D. Md. 1987) (cameras); Kreepy Krauly USA, Inc., 56 Fed. Reg. 1813 (FTC 1991) (proposed consent agreement) (swimming pool cleaning appliances).

66. Germaine Monteil Cosmetiques Corp., 100 F.T.C. 543 (1982) (consent order).

67. Business Elecs. Corp. v. Sharp Elecs. Corp., 485 U.S. 717 (1988).

68. Monsanto Co. v. Spray-Rite Serv. Corp., 465 U.S. 752 (1984). 
tures that made it more likely that a buyer would rely on sales advice. From a sample of twelve recent lower court cases in which unlawful vertical price restraints were alleged, eleven addressed the marketing of branded consumer goods with apparent credence features: clothing (three cases), furniture (two cases), luggage, tires, chain saw replacement parts, steel building construction materials, and automobiles. ${ }^{69}$ There are few cases involving food staples or high volume consumables for which the consumer can more readily determine an informed buying preference. When consumables are subject to vertical price restraints, they tend to be heavily promoted, brand name items that are marketed on the basis of image and credence features (examples include hquor, cosmetics, candy, and patent medicine). ${ }^{70}$ As in the case of Classic Car Wax, sales of brand-distinguished items may benefit from a dealer network willing to promote a brand based on considerations other than low price and infornational advertising.

Measuring the amount of consumer injury from reduced consuiner demand quality will be difficult. Some disguised dealer brand pronotion could have a procompetitive effect (by leading the consumer to a brand that a well-informed consumer would choose, or by helping a new entrant in a concentrated or oligopohistic industry). But, in many cases, the same procompetitive effect could be achieved through producer-level promotion that is easier to monitor and control. ${ }^{71}$ When a dealer has strong financial incentives to sell a particular brand, the scales are tipped against the dealer providing the consumer neutral advice among brands. Indeed, the dealer's incentive will be to dissuade the consumer from any

69. This computer-generated sample includes reported federal cases decided after 1987 that involved allegations of vertical price restraints. The 11 cases involving branded products with apparent credence features are: Bailey's, Inc. v. Windsor Am., Inc., 948 F.2d 1018 (6th Cir. 1991) (chainsaw replacement parts); Parkway Gallery Furniture, Inc. v. Kittinger/Pa. House Group, Inc., 878 F.2d 801 (4th Cir. 1989) (furniture); Sorisio v. Lenox, Inc., 863 F.2d 195 (2d Cir. 1988) (luggage); Jeanery, Inc. v. James Jeans, Inc., 849 F.2d 1148 (9th Cir. 1988) (clothing); Ben Elfinan \& Son, Inc. v. Criterion Mills, Inc., 774 F. Supp. 683 (D. Mass. 1991) (carpeting); Lovett v. General Motors Corp., 769 F. Supp. 1506 (D. Minn. 1991) (automobiles); Toys "R" Us, Inc. v. R. H. Macy \& Co., 728 F. Supp. 230 (S.D.N.Y. 1990) (clothing); Cheatham's Furniture Co. v. La-Z-Boy Chair Co., 728 F. Supp. 569 (E.D. Mo. 1989) (furniture); Sainple, Inc. v. Pendleton Woolen Mills, Inc., 704 F. Supp. 498 (S.D.N.Y. 1989) (clothing); Inter-City Tire \& Auto Ctr., Inc. v. Uniroyal, Inc., 701 F. Supp. 1120 (D.N.J. 1988) (tires); Corrosion Resistant Materials Co. v. Steelite, Inc., 692 F. Supp. 407 (D.N.J. 1988) (steel building materials).

The twelfth case involved allegations by a private brand retail gasoline chain that its supplier had cut it off because the chain had discounted its gasoline. Bi-Rite Oil Co. v. Indiana Farm Bureau Coop. Ass'n, 908 F.2d 200, 202 (7th Cir. 1990).

70. See generally Schwegmann Bros. v. Calvert Distillers Corp., 341 U.S. 384 (1951) (liquor); Dr. Miles Medical Co. v. John D. Park \& Sons Co., 220 U.S. 373 (1911) (patent medicine); Russell Stover Candies, Inc. v. FTC, 718 F.2d 256 (8th Cir. 1983) (candy); Germaine Monteil Cosmetiques Corp., 100 F.T.C. 543 (1982) (consent order) (cosmetics).

71. For exanple, new dealers can be won by lowering the inanufacturer's price. A manufacturer can generally maintain a product's upscale image by maintaining its wholesale price and its innage advertising. See Robert Pitofsky, In Defense of Discounters: The No-Frills Case for a Per Se Rule Against Vertical Price Fixing, 71 Geo. L.J. 1487, 1494 (1983). 
brand predisposition, even one based on informational advertising, consumer publications, or other market information less hikely to mislead the consumer. There is no free rider constraint to diminish the dealer's enthusiasm for such anticompetitive brand promotion: the dealer's mcreased sales are achieved with few added costs and low risk of legal sanctions. When the promotion occurs at the dealer's place of business, it will likely lead to immediate sales. Competing dealers will benefit little froin this activity and have every incentive to mstitute their own on-site promotion.

Prohibiting vertical price restraints will not eliminate all dealer brand promotion that reduces consumer demand quality. Even without vertical restraints, a retailer would still promote sales of the brand offermg the highest retail profit. Such profit differentials are a fact of commercial life. Competitors may often force a retailer to sell popular brands at a lower margin than brands that are less in demand. Nonetheless, without vertical restraints, the imcentives for retailer brand promotion would be substantially reduced: the market forces of imtrabrand competition would constrain profit margins on any item that had achieved significant brand identification.

The car wax case demonstrates the fallacy of assuming that a vertical restraint is procompetitive simply because it increases the output of the producer's product. Some theorists would argue that forcing consumers to pay more for a product does not imply an mefficient allocation of resources because an enhanced product is being sold. Under this view, increased sales, in and of themselves, suggest welfare gains. ${ }^{72}$ However, it is difficult to see how a dealer could significantly enhance the value of a can of car wax. Vertical price-fixing evidently increased sales of Classic Car Wax, but did so despite its apparent inferiority to a number of lowerpriced products. ${ }^{73}$ Similarly, vertical restraints linked with spiffs may mcrease sales of a top-rated electronic good, but they can also mcrease sales of inferior products. In short, the supposed efficiencies brought about through vertical restraints can result only if one assumes a high

72. See BoRK, supra note 11, at 290, 295-96; Frank H. Easterbrook, Vertical Arrangements and the Rule of Reason, 53 ANTITRUST L.J. 135, 163-64 (1984); Klein \& Murphy, supra note 5, at 291; Richard A. Posner, The Rule of Reason and the Economic Approach: Reflections on the Sylvania Decision, 45 U. CHI. L. REV. 1, 18-19 (1977). Scherer suggests that increased output of a single manufacturer is less likely to reflect increased efficiencies if a large number of coinpetitors are relyiug on vertical restraints. See F.M. Scherer, The Economics of Vertical Restraints, 52 ANTITRUST L.J. 687, 701-04 (1983).

73. Bork suggests that if vertical restraints produce product differentiation that results in market power, so too do all promotion and advertising efforts. Seeing no basis to distinguish vertical restraints, he argues that they, like advertising and proinotion generally, should not be per se illegal. See BoRK, supra note 11, at 291 (concluding that "vertical restraints should always be lawful"). As this Article shows, when the focus is on the quality of consuner deinand, there are sound reasons for distinguishing point-of-sale dealer promotion purchased through vertical restraints from advertisiug and proinotion efforts generally. Other welfare effects also distinguish vertical restraints from advertising and proinotional allowances. See infra Sections III.A-B. 
quality of consumer demand, an assumption frequently inconsistent with the use of vertical restraints at the retailer level.

The car wax case also documents the difficulty consumers have in learning of their buying mistakes and rectifying thein. Most of Classic's products were satisfactory or above average in overall consumer ratings. The major weaknesses of Classic's paste wax were its less-than-maximum durability and its extraordinarily high price. Consumers who were satisfied with the mitial shine produced on a car finish might never realize that far less expensive products could produce an equivalent but more durable shine. Although it had fallen further in the ratings, consumers were evidently still buying Classic's high-priced, nonsuperior paste wax twenty years after the product was initially evaluated by Consumer Reports. ${ }^{74}$ Similar lessons could be drawn from the use of hidden dealer brand promotion for consumer electronic products. As long as a television set performs satisfactorily, the consumer may never realize that a more coinpetitive alternative was available.

Finally, the car wax story shows that the anticompetitive effects of vertical price-fixing are not limited to companies with large inarket shares. Even a new entrant or firm with a small market share can use vertical price-fixing to generate on-site dealer promotion. Through such promotion, any producer can generate brand loyalty, or consumer conduct with like consequences, at the cost of reduced quality of consumer demand.

III

\section{Reassessing the Economic Debate on Retail Price-Fixing}

\section{A. The Procompetitive Side of Vertical Price-Fixing}

If, as the Suprente Court assumes in Sylvania and Sharp, vertical price restraints are a tool for increasing retailer brand promotion activity, the umiverse of their potential procompetitive effects is broad, as broad as the potential proconipetitive effects of any brand proinotion activity. Thus, as described in Section II.A, vertical price-fixing could aid a producer $m$ gaining entry, in achieving a more efficient level of output, in informing the public about a new technologically advanced product, or, perhaps imdirectly, in achieving the quality that is needed to sustain brand loyalty. But each of these benefits can be pursued in other ways that are likely to generate fewer negative welfare costs. For exainple, low prices, producer-level advertising, proinotional fees paid to a retailer, or buy-back arrangements with retailers would aid a firm in gaining market

74. In its June 1988 issue, Consumer Reports again evaluated 30 automobile polishes, one of them sold under the name "Wynn's Classic Car Wax." The polish received only average ratings but remained among the four most expensive polishes tested. Auto Polishes, 54 Consumer REP. 377, 379 (1988). 
penetration without reducing intrabrand competition at the retail level. ${ }^{75}$

Given their substantial negative welfare imphications, vertical price restraints can achieve a net welfare gain only if they provide strong welfare benefits. Moreover, these benefits should be of a nature that cannot reasonably be attained by marketing devices with fewer negative costs. Defenders of vertical restraints have recently focused on three potential benefits said to meet this test: (1) the use of vertical restraints to buy dealer promotional services and eliminate free riders; (2) the use of vertical restraints to prevent loss leader sales that undermine the loyalty of full price dealers; and (3) the use of vertical restraints to buy dealer brand certification.

\section{The Expanded Free Rider Rationale}

At the heart of the free rider rationale is a behef that fixed resale prices allow a producer to more effectively promote full service retailmg. ${ }^{76}$ Absent vertical price restraints, consumers will shop for presale services at those outlets that offer them and then make their actual purchases at the store offering the lowest prices. In effect, it is argued, the discounter takes a free ride on the full service retailer who offers presale services. This rationale is irrelevant to postsale services and presale promotional services that directly translate imto higher sales. ${ }^{77}$ Klein and Murphy, who conclude that vertical restraints are frequently procompetitive, agree that only a small segment of a retailer's activities are subject to this form of free ridimg. ${ }^{78}$ Klein and Murphy also observe that dealers, offered additional revenue from fixed resale prices, may simply pocket the gain without providing the additional service that the manufacturer desires. ${ }^{79}$ Alternatively, dealers could use the extra revenue to lower their retail prices on related products that draw consumers into the store (in this manner, non-performing dealers could still attract business from the full service retailer performing all manufacturerdesired services). ${ }^{80}$

Klein and Murphy, however, do not abandon the free rider theory.

75. For a description of these and other negative costs of vertical price-fixing, see infra Section III.B.

76. See Lester G. Telser, Why Should Manufacturers Want Fair Trade?, 3 J.L. \& EcoN. 86, $89-96$ (1960) (making a service argument).

77. Dealers can charge for any postsale service, thus preventing a consumer from taking a free ride at their expense. Many promotional activities, such as a dealer's product selection and shelving or the advice of salesclerks, are low cost and relatively invulnerable to free riding.

78. See Klein \& Murphy, supra note 5, at 267 (vertical restraints not employed "to avoid consumer free riding"); see also SCHERER \& Ross, supra note 25, at 552 (discussing limitations of the free rider argument). Comanor states that "[w]lienever it is feasible to charge separately for the service and the product, no free rider problem necd exist." Comanor, supra note 9, at 103.

79. See Klein \& Murphy, supra note 5, at 266 ("[E]ven if nonprice competition is unidimensional, retailers may merely take the additional money created by the vertical restraint and continue to free ride.").

80. See id. 
Instead, they broaden its base to provide "an empirically relevant procompetitive explanation for vertical restraints." manufacturers use vertical restraints to compensate dcalers "for an increased supply of product promotion services and to prevent price competition that would eliminate the desired . . . marketimg scheme." The failure to maintain the desired marketing scheme could undercut the manufacturer's product reputation to the detriment of the manufacturer's overall sales. ${ }^{83}$ Their analysis assumes that "inanufacturer monitoring and the threat of manufacturer termination assures dealer perforinance."84 In effect, the producer will be buying dcaler loyalty or, im their words, employing a "contract enforcement mecharnisin" 85 by creating an environment in which dealers will be more likely to perforn the range of activities the producer seeks. This broader theory is consistent with arguments made by Louis Brandeis early in this century ${ }^{86}$ and with the Supreme Court's reasonimg in Sylvania and Sharp that vertical restraints are broadly procompetitive because they encourage dealer promotion and service activities that heighten coinpetition among brands.

Klem and Murphy offer examples of cases in which their expanded free rider theory would justify the use of vertical price-fixing. ${ }^{87}$ Among thein are the Coors Company's distribution scheme involving exclusive territories for its distributors and resale price maintenance for its retailers (said to be necessary to ensure that both distributors and retailers maintamed refrigeration and appropriate product rotation to prevent the sale of stale beer); ${ }^{88}$ Levi Strauss' resale price inaintenance scheme on

81. Id. at 296.

82. Id. at 267.

83. See id. at 281 (discussing failure to maintain marketing system with Coors beer example).

84. Id. at 267.

85. Id. at 265 .

86. See Grimes, supra note 62 , at $1294-96$.

87. See Klein \& Murphy, supra note 5, at 280-82, 289-90.

88. See Adolph Coors Co. v. FTC, 497 F.2d 1178, 1182 (10th Cir. 1974) ("Because of the delicacy of the product, it is essential that the refrigeration controls and expeditious marketing techniques be strictly momitored."), cert. denied, 419 U.S. 1105 (1975). Coors unpasteurized beer was said to have a shorter shelf life than other brands. See Klein \& Murphy, supra note 5, at 281. Klein and Murphy beheved that the resale price maintenance scheme was necessary to generate tlie financial imcentives for dealers to inaintain the necessary refrigeration and product rotation. See id. at 280-82.

Elsewhere, Klein and Murphy question whether fixed resale prices will end the free rider problem (because retailers will use the imcreased revenue in ways other than those desired by the manufacturer). See id. at 266 . Thus, without monitoring, there is no assurance that retailers will provide the desired services. Coors might decrease the cost of such a monitoring scheme by printing a "sell by (date)" label on beer packaging, allowing consumers to determine for themselves the freshness of the becr. 
jeans; ${ }^{89}$ and Monsanto's termination of a price-cutting herbicide dealer. ${ }^{90}$ In each case, the authors contend that vertical price inaintenance was justified to sustain the cost of dealer pronotion services. ${ }^{91}$ This analysis does not establish convincingly why nonitoring of traditional contractual requirements and rewards would not have achieved the desired dealer services with fewer anticompetitive effects.

\section{Avoiding Loss Leaders}

A second asserted procoinpetitive benefit for vertical price-fixing is that it enables a manufacturer to prevent loss leader selling by a dealer that might deter full price dealers fronı offering the product. This argument, said to be advanced by producers more than academics, ${ }^{92}$ does not suggest a free rider problen, but merely that a nıanufacturer needs resale price maintenance to maintain a full dealer network. The argunient finds indirect support in Robert Steiner's observation that a retailer desiring to bring new custoners into the store through advertised, low-price specials can do so most effectively by advertising a well-known brand. ${ }^{93}$ Advertisements for lesser-known brands are likely to bring in fewer custoniers. When an aggressive retailer begins discounting a well-known brand, the producer may conie under pressure fron full price retailers who threaten to discontinue the product. However, it is open to question whether these dealers will carry out their threats.

Steiner docuinents the negative correlation between the strength of brand loyalty and the retail markup. As brand strength increases, retailers are forced to lower their prices to compete for sales of that brand. It is not in the producer's interest to cut off the discounter because lower retail margins will increase overall sales of the well-known brand without undercutting the producer's profit niargin. Most retailers dare not abandon the well-known brand because its absence froin their shelves niay cause custoiners to shop elsewhere. ${ }^{94}$ The result nuay be otherwise if consumer brand loyalty is weaker. To niaintain dealer networks, producers of products with less brand recoguition nay feel pressure to lower the

89. The Levi Strauss litigation is described in Sharon Oster, The FTC v. Levi Strauss: $A n$ Analysis of the Economic Issues, in IMPACT EVALUATIONS OF FEDERAL TRADE COMMISSION Vertical Restraint Cases 47, 51-54 (R. N. Lafferty et al. eds., 1984).

90. See Monsanto Co. v. Spray-Rite Serv. Corp., 465 U.S. 752, 755-59 (1984) (recounting facts of the case).

91. Klein and Murphy fail to explain in many of these cases wlyy their own criticism of traditional free rider theory-tliat dealers would take tlie additional premium but avoid compliance with the promotional requests-would not apply.

92. See, eg., Kevin J. Arquit, Resale Price Maintenance: Consumers' Friend or Foe?, 60 ANTITRUST L.J. 447, 455 (1992) ("Another efficiency story lias been advanced more by businessmen interested in instituting [resale price maintenance] than by academics . . . .").

93. See Steiner, supra note 42, at 397 ("Multiproduct retailers liave a far greater incentive to promote popular brands than 'blind merchandise,' because featuring a popular brand at a belowmarket-price draws store traffic that will also purcliase ligher markup items.").

94. See Steiner, supra note 21 , at 162 (noting the lold of popular products over consumers). 
price charged distributors or retailers or to implement vertical pricefixing. ${ }^{95}$

Should the holder of a weak brand be allowed to maintain retail prices to prevent discounting that may undermine a dealer network? To answer affirmatively is to recognize an expanded predatory pricing prohibition for intrabrand competition. A major criticisin of older predatory pricing decisions is that they prevented legitimate price competition that is beneficial to consumers. The same will be true of any rationale that allows the use of vertical price-fixing to prevent the discounting of weak brands. A producer whose product does not have strong brand loyalty can seek to maintain its dealer network in other ways that have fewer welfare costs: selling to retailers at lower prices, improving the product, expanding advertising, or instituting a systein of proinotional allowances to increase dealer services.

\section{Image Certification}

A third potential benefit of vertical price-fixing is its use to obtain a retailer's product certification. A brand that is carried by Tiffany's or Neiman-Marcus might enjoy a status among consumers that enhances its reputation and increases overall sales. One way of making it attractive for a high-end outlet to carry a particular brand is to guarantee a high retail inargin through a fixed retail price. To ineasure the welfare effects of such conduct, one inust first determine whether image certification benefits consuiners. If it does, there is still a question whether vertical restraints are the least costly route to achieve that benefit.

Manufacturers inay use vertical restraints as a part of an overall plan to promote a product's image. Classic Car Wax was apparently sold in an elegant, shiny black can at relatively high fixed retail prices. This marketing strategy apparently attracted dealer outlets and increased sales. Similarly, a inanufacturer of designer jeans may be able to increase sales substantially with an upscale inarketing image achieved through appropriate advertising and vertical price-fixing designed to encourage dealer proinotion (or to convince high-inage dealers to carry the jeans). For the manufacturer, the result can be increased production efficiencies and higher sales. But has consumer welfare been enhanced? Do consumers get higher quahity jeans for the higher price they pay? Or are consumers simply enticed by non-informational aspects of the inarketing scheme to buy an expensive image label?

Some theorists are reluctant to draw value judgments about the utility of various consumer choices, even when those choices may be based on image appeals that obscure the product's objective performance. It has been argued, for example, that the purchaser "consumes" the prod-

95. See id. at 163-64 (discussing the marketing of "weak" brands). 
uct's mental image along with its physical characteristics. ${ }^{96}$ The argument has its appeal. A teenager may be happier for appearing in Guess? jeans, regardless of a more objective quality-price comparison. But the question should be rephrased to determine the net welfare effect: Are consumers more satisfied with Guess? jeans and the accompanymg image carried as the result of image advertising than if they had never been exposed to the image promotion and were wearing a competitor's jeans? ${ }^{97}$

Assuming that image advertising does increase consumer satisfaction or bring production and marketing efficiencies, the argument that this justifies use of vertical price-fixmg falters when the brand promotion is effected by a retail outlet not known to consumers as "high-end." Except in high image stores, a retailer's decision to carry oue brand and not another involves no significant image promotion. If a converience store carries only a single brand of car wax, it is unlikely that the particular brand's image has been significantly enhanced.

A producer can limit distribution to prestige outlets through selective, nonprice vertical restraints. If the producer wishes to achieve wider distribution, vertical price-fixing may be one way of guaranteeing that the prestige outlet is not undersold. But use of vertical price-fixing causes welfare costs to inount. In effect, all retail outlets, no matter how efficient, are being asked to maintain the high markup to keep the prestige outlet on line. The producer is forcing his customers to subsidize the availability of this product in a prestige outlet where most consumers do not shop.

Inage advertismg at the producer level avoids these welfare costs. Moreover, there may be inore efficient ways of paying for whatever promotion value the prestige outlet is offering. Steiner reports that the fashion industry has found a way to keep its higher-margin retail stores through differentiated prices. Although varied pricing inay raise issues of unlawful discriminatory pricing, apparel manufacturers have apparently offered department store customers margin guarantees, merchandise return privileges, and advertising allowances not available to offprice retailers. ${ }^{98}$ Assuming the legal pitfalls of such discrimination can be avoided, this inarketing approach has fewer welfare costs than vertical price restraints.

96. See Economides, supra note 22 , at 533,535 (discussing the importance of a product's "mental image").

97. Cf. SCHERER \& Ross, supra note 25 , at $579-80$ (discussing whether advertising "adds more to economic welfare than its costs" and analyzing how advertising affects utility through the creation of socially desirable images).

98. See Steiner, supra note 21 , at 172 n.52 ("The discriminatory strategy can presently be observed in some apparel lines, where manufacturers provide their department store customers with margin guarantees, merchandise return privileges, and advertising allowances not available to their off-price customers, who are quite willing to be discriminated against to obtain the highly desirable lines."). 
Current procompetitive rationales for vertical price restraints properly shift the focus away from the narrow free rider theory and onto the broader brand promotion benefits that such restraints may provide. But these benefits should not be overstated. As more and more competing producers employ vertical restraints, the benefits will be increasingly selflimiting. A retailer who is guaranteed a high margin on a number of competing brands subject to retail price maintenance no longer has an incentive to push one of these brands over another. Thus, although the collective effect of mdustry-wide use of vertical price-fixing may be negative, no one producer may dare ehmmate the practice for fear of giving a comparative advantage to competitors who retain it. ${ }^{99}$

Finally, the case for vertical price-fixing is not made by showing good intentions of producers or even that fixed prices can lead to a producer-desired product-service mix. Even if these desired effects occur (and Klem and Murphy correctly question the compliance of retailers), vertical price-fixing has substantial and inevitable anticompetitive effects that must be weighed to determine its net welfare effect.

\section{B. Welfare Losses from Vertical Price-Fixing}

In order to provide a net benefit to society, vertical restraints must overcome the combined effect of three types of welfare costs associated with their use: (1) the cost of any decrease in the quality of consumer demand; (2) the producer's cost of admimistering the restraint; and (3) the welfare loss associated with diminished competition at the retail (and possibly the producer) level. The first of these costs, likely to occur when vertical restraint shifts brand promotion incentives to the retailer, was addressed im Part II. Economic theory and evidence relating to the second two costs are summarized below.

\section{Monitoring and Enforcement Costs}

The producer's costs in admimstering a vertical price restraint are frequently overlooked. From the producer's perspective, the cheapest distribution system is one im which the product is delivered to a purchaser at the factory gate, no strings attached. As soon as the producer becomes involved in regulating downstream marketing practices, there are implementation and enforcement costs. These administrative outlays do not directly pay for any dealer service or promotion activity that might benefit consumers. For some vertical restraints, such costs may be mimimal. For example, limitimg the locations from which an automobile dealer may sell vehicles probably imposes low enforcement costs on the producer. A system of fixed retail prices, on the other hand, often involves significant implementation and enforcement costs, particularly

99. See Scherer, supra note 72 , at 701-04. 
for well-known brands with wide distribution networks. ${ }^{100}$

Market observations support this conclusion. For example, Steiner describes the substantial funds paid by General Electric to nionitor resale price maintenance schemes during the $1950 \mathrm{~s} .{ }^{101}$ His analysis indicates that even a sinall number of producer-nistituted enforcement actions are likely to generate substantial legal fees. ${ }^{102}$ Steiner has also documented the difficulties a toy producer faced when attenipting to momitor retail pricing by discount retailers and their suppliers, both skilled at covering their tracks. ${ }^{103}$ Although these enforcement costs might go down if vertical price-fixing were not subject to legal restrictions, the monitoring cost will remain substantial for any producer with a large retailer network. The incentive for a retailer to cheat on the price becomes substantial if a small reduction im retail price increases sales disproportionately.

Of course, the substantial costs of implennenting vertical restraints should be measured against the distribution steps that a producer might take if vertical restraimts were not permitted. In the absence of restraints, a producer might choose to spend additional money to advertise, to pay promotional allowances to retailers, or even to integrate vertically into retailing. Except for vertical integration, which would entail substantial costs, most of the alternative marketing strategies would probably cost less to implenient than vertical price restraints. There is no problent with monitoring and enforcement when the producer does its own advertising and promotion. Even promotional allowances (for exainple, paying a retailer to prominently shelve the producer's product, to advertise it, or to provide additional service) would appear relatively easier to momitor. Steiner, describing his own experience as an executive for a toy conpany, concludes that promotional allowances are more efficient than vertical restraints in inducing dealers to perform special services. ${ }^{104}$

Although the costs of admimistering a vertical price restranit are a welfare loss, int theory the loss could be absorbed by the producer. But because such price restraimts end imtrabrand price competition at the retail level and because the impact of imterbrand price competition is likely to be undermined by retailer brand promotion associated with the

100. Steiner reports that prior to abandoning its retail price maintenance policy in 1958 , General Electric had signed approximately 30,000 fair-trade agreements and initiated 3,000 lawsuits, spending about \$1 million annually to enforce its program. See Steiner, supra note 21, at 170 .

101. See supra note 100.

102. See Steiner, supra note 21, at 165-71. Even during years when the Fair Trade Laws were widespread, manufacturers had difficulty making resale price maintenance work in many industries. The difficulties encountered in one state are detailed in Ewald T. Grether, Experience in California with Fair Trade Legislation Restricting Price Cutting, 24 CALIF. L. REV. 640 (1936). For a more generalized account of the problems with implementing resale price maintenanee, see Carl H. Fulda, Resale Price Maintenance, 21 U. CHI. L. REV. 175 (1954).

103. See Steiner, supra note 42 , at 40406 (recounting the experiences of the Kenner Products Co.).

104. See id. at $386,402,410$. 
restraint, the producer has both the incentive and the opportunity to pass these costs to the next level.

\section{Loss of Retail Intrabrand Competition}

Consuiners pay more for any price-fixed brand. Because vertical price-fixing ends direct price coinpetition ainong retailers for the affected brand, the benefit of a retailer's lower rent, lower labor cost, or more efficient retailing systein cannot be directly passed to the consumer as a lower purchase price. ${ }^{105}$ A store inust charge the prescribed price on the branded itein, regardless of its own efficient or inefficient inethods. Even if all stores have equal selling costs, they will not necessarily choose the saine inethod of sales. Soine retailers will opt to provide a full range of services; others will provide discount prices with fewer services. When vertical price-fixing is imposed, even if retailers implement all the additional services desired by the producer (absent strict inomitoring, this seems unlikely), inany consumers will be forced to pay for a service they do not desire. The consumer is denied a choice between a discount, nofrills purchase and a higher priced, full-service purchase. ${ }^{106}$

Will the welfare loss froin higher retailer prices be himited because consumers will switch to competimg brands? To some degree, as the price differential increases, consumers will seek out cheaper alternatives. But this tendency will be limited by the increased retailer brand promotion associated with vertical price restraints. Retailers can be expected to work hard to keep consumers from switching brands. Because decreases in consuiner demand quality are likely to be associated with this activity, welfare losses could be substantial.

\section{Dynamic Efficiency in Distribution}

So far, the analysis presented here has focused on allocative efficiency, the efficiency benefit that flows from an effective allocation and distribution of goods and services. That is a natural focus for vertical restraimts, which are built into the distribution system. But economists

105. As Klein and Murphy point out, an efficient retailer unight still pass on the benefits of his lower cost operations through nonprice competition or lower prices on other products. Klein \& Murphy, supra note 5, at 266. These same comineutators implicitly acknowledge that alternatives to direct price competition will be less effective. See id. at 277 (recognizing that although nonprice competition may be less efficient than price competition, it may still "reduce the effectiveness of resale price inaimtenance in assuring dealer perforinance").

106. See SCHERER \& Ross, supra note 25, at 548; Comanor, supra note 9, at 107. Arquit answers that consumers may turn to other brands that are discounted. See Arquit, supra note 92, at 460. The hikelihood of consumers turning to other brands will be limited if vertical restraints are widespread, if hidden brand promotion decreases consumer demand quality, or if consuiners, for legitimate reasons, have developed brand loyalty to a product subject to vertical price-fixing.

Arquit also notes that consumers can be forced to buy unwanted features or scrvice whenever the inanufacturer decides to include such items in the sale package. Id. When there is active interbrand and intrabrand coinpetition, a manufacturer's package of goods and services not desired by consumers will not survive in the marketplace. 
say that over time, far greater benefits to consumer welfare flow from dynamic efficiency: the ability of the economy to innovate and bring to market new goods and services. ${ }^{107}$ In Sylvania, the Supreme Court stressed that a vertical restramt could encourage aggressive retailers to make investments in the marketing of new products or the products of new manufacturers. ${ }^{108}$ This ability to enter and penetrate markets is critical for dynamic efficiency. Does it follow that vertical price-fixing is a key to ensuring the dynamic efficiency of our economy?

As already discussed, a new entrant can wim dcaler loyalty without ending intrabrand competition among retailers. The inanufacturer can lower its prices, initiate effective advertising, offer promotional fees, agree to buy back unsold stock, or even make use of less competitively oppressive, non-price vertical restraints. Even if all these steps were taken together, they probably would not carry the anticompetitive baggage of a vertical-price restraimt.

From the producer's poimt of view, an advantage to vertical pricefixing is that it transfers the financial risk of promotion to the distributor or retailer. Some of the alternatives to price-fixing, although more easily controlled by the producer, would not allow the producer to shift the promotion risk. But an agreement to buy back unsold merchandise, albeit not shifting the ultimate risk, would not require the producer to advance up-front capital. And non-price vertical restraints that do not eliminate intrabrand retail competition would allow some shifting of the promotion risk.

Even if a vertical price restraint occasionally offers umique, otherwise unattainable benefits to a new entrant, one should not rush to the conclusion that vertical restraints produce net benefits for dynamic efficiency. To understand fully the inipact of any vertical restraimt, one must also consider dynamic efficiency within the distribution system. The entry and exit of retailing firms, and the ability of retailers to undertake new approaches and methods to retailing, have played a key role in enhancing consumer welfare in the United States. The distribution system of the early twentieth century may have been efficient in its time. But if that system had been welded in place, stopping evolution based upon changes in transportation, commumication, and population patterns, or stifling the imagination of an innovative distributor, consumer welfare would have suffered greatly.

Antitrust policy has too often focused on the producer as the key to competition. Holmes argued that the producer knows best how to improve his business in a mamier consistent with the public interest. ${ }^{109}$ But this producer-centered view ignores the substantial role of the distri-

107. SCHERER \& Ross, supra note 25 , at $613-14$.

108. Continental T.V., Inc. v. GTE Sylvania Inc., 433 U.S. 36, 55 (1977).

109. See Dr. Miles Medical Co. v. John D. Park \& Sons Co., 220 U.S. 373, 412 (1911) (Holmes, 
bution industry. One estimate is that between thirty-four and thirtyeight percent of each consumer dollar flows to wholesalers and retailers, an amount equal to or in excess of the producers' share. ${ }^{110}$ This statistic alone suggests caution before accepting the premise of Sylvania and Sharp that interbrand coinpetition among producers is the primary engine that drives our competitive economy. So, too, do the numerous innovations that have marked distribution activities over the years. ${ }^{111}$ Today, large specialty discount retailers, warehouse stores, department stores, and expanded mail order stores dot the landscape. The sinall independent retailer that dominated im Justice Holmes' time is a less significant presence. Large cham stores are the foundation of many retail market seginents.

Vertical price-fixing directly affects the dynamic efficiency of distribution. It may also affect innovation at the manufacturer level, particularly if its use is linked to other vertical restraints that lock in patterns of distribution. A stultified distribution systein can make it more difficult for new manufacturers or existing inanufacturers with new products to reach the public. Perhaps the difficulty of U.S. producers in gaining entry to the Japanese domestic market is a good example. Thus, although one cannot predict whether a particular vertical restraint will enhance or hinder innovation over the long term, it is possible to reach conclusions about the impact of widespread use of a restraint such as vertical price-fixing. Such use would likely have a strongly negative impact on the dynanric efficiency of the distribution seginent. Innovative methods of retailing that offered consuiners lower prices would be blocked. In addition, if use of vertical price restraints locked in distributional patterns, there could be strongly negative ripple effects for the dynannic efficiency of product and service innovators. Isolated use of vertical price-fixing (as long as its use is not widespread in any industry) would probably have minimal negative effects on dynamic efficiency. The legal standard governing vertical price restraints should, however, be chosen to ensure that such widespread use does not occur.

\section{The Welfare Balance Sheet for Vertical Price-Fixing}

If vertical price-fixing has any procompetitive effects, they must be of sufficient magnitude to offset the costs described above. Welfare losses

J., dissenting) ("I see nothing to warrant my assuming that the public will not be served best by the company being allowed to carry out its plan.").

110. See Steiner, Intrabrand Competition, supra note 22, at 195 ("Historically in the U.S. consumer goods economy the combined share of the overall retail dollar going to retailers and wholesalers has been in the $34 \%-38 \%$ range.").

111. See Oversight Hearings on Authorization for the Antitrust Div. of the Dep't of Justice Before the Subcomm. on Monopolies and Commercial Law of the House Comm. on the Judiciary, 99th Cong., 1st Sess. 12, 15-16 (1985) [hereinafter House Oversight Hearings] (statement of Lawrence S. Sullivan). 
due to these costs will occur regardless of the motivation for, and any possible procompetitive effect of, a price-fixing arrangement. Moreover, many of these costs will occur even if there is effective interbrand competition. ${ }^{112}$

Large retail chains often enjoy substantial leverage over even the largest producers, who seek additional outlets for their products. A large retailer can use this leverage to force vertical price restraints on the manufacturer. ${ }^{113}$ As the Classic Car Wax story shows, producers often are the instigators of retail price-fixing schemes. But producers do not act in a vacuum; the producer may be pushed to provide vertical price-fixing as an imcentive to buy dealer outlets or loyalty. ${ }^{114}$ When producers are starved for outlets, even small retailers are able to play producers off against one another im choosing brands that offer the most favorable retailer profit margin. In some cases, insecure producers, possibly under dealer pressure, may mistakenly impose or continue vertical restraints despite brand loyalty that wonld allow the producer a higher return without these restraints. Stemer's data show that Levi's sales volume and profit margin increased after the Federal Trade Commission forced Levi's to drop its vertical price-fixing scheme. ${ }^{115}$

This is part of the ongoing rivalry between producers and retailers. Harking back to Ward Bowman, ${ }^{116}$ Stemer shows that the traditional, producer-centered econoimc view is madequate to explain this interaction. ${ }^{17}$ Under Stemer's dual economic model, retailers and producers compete against one another to gain a larger portion of the limited revenue available from consumer purchases. Although some distributional

112. Vertical restraints will be of value to producers only if they can generate sufficient brand loyalty to diminish interbrand competition. See supra Section II.C. If there is effective interbrand coinpetition, the adininistrative costs of a vertical restraint are less likely to be passed on to the consuner. But soineone must pay these administrative costs; they remain a deficit item on the allocative efficiencies account.

113. See House Oversight Hearings, supra note 111, at 15-16; Comanor, supra note 9, at 113 (discussing the inonopsony power of large distributors in regard to their suppliers); $c f$. Klor's, Inc. v. Broadway-Hale Stores, Inc., 359 U.S. 207, 210-14 (1959) (holding that a large department store chain had unlawfully conspired with producers to deny product to the plaintiff, a sinall retail appliance store in competition with the chain). The view that retailers are frequently the force behind vertical price-fixing is supported by case analyses. See Bowman, supra note 21, at 832-48; Victor H. Krainer, Legislating Fair Trade by Foul Means (1937-1939), 36 ANTITRUST BuLL. 81, 90 (1991).

114. See Steiner, supra note 42 , at 391 .

115. See Steiner, Sylvania Economics, supra note 22, at 57-58. But see Klein \& Murphy, supra note 5 , at 290 (questioning the argument that the FTC did Levi Strauss a favor by forcing removal of the price inaintenance scheme, but offering no einpirical support).

116. Bowman, supra note 38.

117. See Steiner, Intrabrand Competition, supra note 22, at 198-99. Steiner's writings further develop insights of earlier economic writers who saw resale price maintenance as a part of the negotiations between dealers and producers as to the margin each would receive. See Grether, supra note 102, at 698 ("The essence of resale price control in the drug trade in California is that the vertical price factors becoine affeeted by soine anount of organized bargaining between retailers and manufacturers."). 
arrangements can imcrease consumer demand to the benefit of both producers and retailers, there is a constant rivalry between the two groups to determine the precise allotment of consumer revenue. Steiner shows that prescient producers will reject vertical restramts if a branded product already commands consumer loyalty. If brand loyalty exists, retailers anxious to entice customers will ask to carry the producer's brand independently of any incentive offered by a vertical restraint. Moreover, if consumers can purchase the branded product from multiple sources and easily compare prices, retailers will be pushed to narrow their profit margin im order to compete on price. The result can be that consuiners will pay less for the promoted brands, and, as recent studies suggest, for competing brands as well. ${ }^{118}$

Recent analysis bears out the substantial welfare-enhancing effects of maintaining imtrabrand retail price competition. Steiner shows that the elimination of vertical price-fixing in the toy industry during the 1950 s helped to spark a surge of price coinpetition among dealers. Despite the reduction in interbrand competition (keyed to the imcreased brand loyalty promoted by television advertisements for toys) and the increase $\mathrm{m}$ prices charged by producers, the retail prices paid by consumers dropped, solely as the result of increased intrabrand price coinpetition ainong retailers. ${ }^{119}$ More recently, the elimination of vertical price maimtenance on Levi Strauss' jeans brought consuuners lower net prices despite higher producer prices charged to retailers. Steiner finds evidence that the elimination of vertical restraints in the jeans industry produced more invigorated intrabrand competition anong retailers and, ultimately, more effective interbrand coinpetition as well. ${ }^{120}$ Similarly, Willard Mueller's study of the impact of elimination of vertical pricefixing on Sealy mattresses showed welfare gains through lower retail prices on Sealy as well as coinpeting brands of mattresses. ${ }^{121}$ These results belie the Supreme Court's assumption that vertical price restraints provide net competitive benefits. Instead, at least for industries as varied as toys, mattresses, and jeans, it would appear that vertical price restraints either decrease interbrand competition, or increase it insufficiently to offset the loss in retail, intrabrand coinpetition.

Moreover, the Steiner analysis reinforces the concern that vertical price-fixing is frequently associated with dealer brand promotion that reduces consumer demand quality. If a producer promotes brand loyalty through an advertising campaign, the risk of anticompetitive results is reduced because of more effective momitoring mechamisms and consumer awareness of the self-imterested nature of the promotion. There is coin-

118. See, e.g., Steiner, Intrabrand Competition, supra note 22, at 163-75, 182-85.

119. See Steiner, Sylvania Economics, supra note 22, at 55-57.

120. Id. at 57-58.

121. See Mueller, supra note 23, at 1293-96. 
petition at the retail level that may keep retailers from passing on to consumers much of the increased promotion cost that the producer passed on to them. If, however, the producer is unwilling or unable to establish brand loyalty through its own promotion efforts, it may choose to attract dealers througli vertical restraints. As discussed in Part II, however, the shift of promotion activity from the producer to the retail level is likely to reduce the quality of consumer demand.

In Sharp, the Supreme Court wrote that if the vertical price-fixing prohibition were strengthened, producers might be restricted to otler, less efficient ways to promote their brands. ${ }^{122}$ As Steiner's toy industry example shows, not all producer-generated brand promotion is inefficient. Curtailing the use of vertical restraints may place more of the burden of brand promotion back at the producer level where tlie opportunity for anticoinpetitive marketing is narrower and the control mechanisms more effective. Limiting the use of vertical restraints to purchase dealer promotion and discouraging the marginally interested producer from undertaking this strategy are consistent with a higher quality of consumer demand and net welfare benefits for our economy.

\section{CONCLUSIONS}

In 1981, Assistant Attorney General Willianı Baxter told a congressional subcommittee that "tliere is no such thing as a harmful vertical practice."123 Mr. Baxter explanied to the saine subcommittee in 1983 why vertical arrangenents could not be harmful without horizontal concentration: "I think there is not an economist in the world who would not agree with the proposition that if there is no concentration either at the upstream level or at the downstream level, the agreeinent camot possibly have anticompetitive consequences." 124

These remarks were offered in support of a hands-off policy toward vertical restraints, including vertical price-fixing. The analysis offered here suggests a quite different policy conclusion. Vertical restraints are frequently harmful to coinpetition. And that harm is often unrelated to the market share of the producer or retailer. Indeed, the pure monopohist or producer with a secure market miche is unlikely to engage in vertical price-fixing: such a producer will be able to gam maximum return by encouraging the narrow retailer margins associated with vigorous intrabrand price competition.

Vertical price restraints are far more hikely to be associated with

122. See Business Elecs. Corp. v. Sharp Elecs. Corp., 485 U.S. 717, 725 (1988).

123. Oversight Hearings on Antitrust Div. of the Dep't of Justice Before the Subcomm. on Monopolies and Commercial Law of the House Comm on the Judiciary, 97th Cong., 1st \& 2d Sess. 7 (1981-82).

124. Oversight Hearings on Antitrust Div. and Office of Legal Counsel of the Dep't of Justice Before the Subcomm. on Monopolies and Commercial Law of the House Comm. on the Judiciary, 98th Cong., 1st \& 2d Sess. 131 (1983-84). 
producers such as Classic Car Wax, which lacked upstream or downstream marketing power. When such producers are unable or unwilling to compete on price, vertical price restraints become a viable option for buying a loyal dealer network. Up to a point, this marketing strategy will work to increase the producer's sales, albeit at the likely cost of consumer demand quality. But as more competing producers adopt the same marketing strategy, welfare costs mount and output increases for individual producers are diluted.

The evidence seems clear that the Supreme Court erred in Sylvania and Sharp when it concluded that vertical restraints would routinely increase welfare by imvigorating competition between brands. At least for vertical price restraints, the negative welfare costs appear substantial. Steiner and Mueller's empirical evidence suggests that lessened interbrand competition is often linked to vertical price restraints and that, in any event, any welfare gains from such restraints are likely to be more than offset by the loss of retail, intrabrand competition. The availability of less costly alternative strategies for pursuing most procompetitive distribution goals further undermines the Court's approach.

These conclusions suggest the wisdom of the Dr. Miles line of cases that culminated in a per se prohibition of vertical price-fixing. The complexities of sorting out procompetitive, berign, and anticompetitive dealer brand promotion (and the difficulty in monitoring dealer conduct) weigh against a rule-of-reason approach to vertical price restraints. Courts are ill-equipped to carry out such open-ended balancing tasks involving potentially limitless economic data and conflicting expert testimony. A simple rule proscribing minimum resale price maintenance is more easily understood and enforced.

In addition, the conclusions reached here run counter to the exception to the per se rule for the producer's unilateral imposition of a retail price maintenance scheme (the Colgate doctrine). ${ }^{125}$ The consequences of fixed resale prices are the same whether or not a conspiracy can be proven. Thus, as one econormist has suggested, the exception should be eliminated. ${ }^{126}$ Finally, the conclusions suggest caution in arguing for an exception to the per se rule for new entrants or small firms. ${ }^{127}$ As the Classic Car Wax case shows, the anticompetitive effects associated with dealer product promotion are not limited to firms with large market shares. Indeed, the frustrated producer unable to compete on price or

125. See United States v. Colgate \& Co., 250 U.S. 300, 307 (1919) ("In the absence of any purpose to create or maintain a monopoly, the [Sherman] act does not restriet the long recognized right of trader or manufacturer engaged in an entirely private business, freely to exercisc his own independent discretion as to parties with whom he will deal.").

126. See George A. Hay, Observations: Sylvania in Retrospect, 60 ANTITRUST L.J. 61,66 (1991). I argued this point at greater length in Grimes, supra note 62, at 1315-16.

127. See Overstreet \& Fisher, supra note 53, at 51; Pitofsky, supra note 71, at 1495. 
informative advertising may be the first to invoke vertical restraints that undermine consumer demand quality.

More broadly, the problems associated with dealer brand promotion and the mounting evidence of negative welfare effects associated with vertical restramts require reexamination of the language in Sylvania that suggests a broad array of procompetitive benefits for non-price vertical restraints. ${ }^{128}$ Strong nonprice distributional restraints can produce the saine incentives for dealer brand promotion and the same negative welfare effects that vertical price restraints generate.

128. Steiner presuines that Sylvania's restraints were welfare enhancing, but concedes the lack of any quantitative study. See Steiner, Sylvania Economics, supra note 22, at 47. After Sylvania inposed the territorial restraint, the coinpany's market share rose froin one or two percent to five percent. Continental T.V., Inc. v. GTE Sylvania Inc, 433 U.S. 36, 38 (1977). But it is unclear what role the vertical restraint played in the increased market share. It is in any event uncertain whether consumers benefitted from purchasing more Sylvania brand televisions, or whether point-of-sale retailer brand promotion came at the expense of the quality of consumer demand. 
